\title{
A new Miocene Formation from The Peotillos-Tolentino Graben fill, Western Sierra Madre Oriental at San Luis Potosí, Mexico: Part 2, Depositional environments and regional significance
}

\author{
Ismael Ferrusquía-Villafranca ${ }^{1}$, José E. Ruiz-González ${ }^{1}$, José Ramón Torres-Hernández², \\ Enrique Martínez-Hernández ${ }^{1}$, Jorge Gama-Castro ${ }^{1}$ \\ ${ }^{1}$ Instituto de Geología, Universidad Nacional Autónoma de México, Ciudad Universitaria, C.P. 04510, México, Distrito Federal, \\ México. \\ ${ }^{2}$ Instituto de Geología, Universidad Autónoma de San Luis Potosí, Ciudad Universitaria, C.P. 78000, San Luis Potosí, S.L.P., México. \\ *ismaelfv@unam.mx
}

\begin{abstract}
The discrimination and characterization of the depositional systems registered in the formal lithostratigraphic units of our country, is practically a pending task of Mexican Geology, notwithstanding their academical and applied importance in the investigation of placer mineral deposits and of aquifers. As a contribution to fill this gap, the depositional systems of the Late Miocene San Nicolás Formation, the major sedimentary fill of the Peotillos-Tolentino Graben, are described and characterized.

The study area lies in San Luis Potosí State, within the Sierra Madre Oriental Morphotectonic Province [SMO], between 22 ${ }^{\circ} 11^{\prime}$ $-22^{\circ} 19^{\prime} \mathrm{N}$ Lat. and $100^{\circ} 30^{\prime}-100^{\circ} 39^{\prime} \mathrm{W}$ Long. and an altitude of $1295-2025$ masl. Such unit is an $\sim 1100 \mathrm{~m}$ thick, fluvio-lacustrine, largely calcilithitic, $15^{\circ}-20^{\circ} \mathrm{NE}$ dipping, peneplained sequence, unconformably overlain by a Quaternary, $\sim 40 \mathrm{~m}$ thick, calcilithiticvolcarenitic blanket, locally covered by mafic lavic/pyroclastic rocks.

San Nicolás Formation includes these systems: Fluvial, lacustrine, debries flow and pyroclastic [the latter two are volumetrically negligible]. The first consists of these lithofacies: (1) Gm, Gh, Gp: Channel lag deposits. (2) Gm, Gp, Sp, St: Bars of various types. (3) Sr, Sl, Fl; Floodplain deposits; it bears the Late Miocene Paso del Águila local fauna and palynoflora, which discloses the presence of pine-oak forest with a well developed understory component, and savanna, as well as a much more humid climate regime then than that prevailing at present. (4) Gh, Sp: Thin channel conglomerates and/or sandstone deposits. (5) Sl, Fl: levee deposits. (6) Sp, Sr, F1: Crevasse splay deposits. Paleosols [associated to floodplain deposits]: Fluvisol, Calcisol, Gleysol and Luvisol. The lake system includes these lithofacies: (1) Lacustrine-carbonate, (2) -fine clastics, (3) -shore, and (4) -mud flats. The debries flow includes lithofacies Gms and Sm.

The great thickness of this continental unit largely records the cyclic superposition of fluvial systems that took place in a basin subsiding pari passu with sedimentary accumulation, under humid to subhumid conditions interrupted by others of [?seasonal] dryness. Finally, the use of plant taxa as paleoaltitude indicators, and the discovery of pre-Pleistocene paleosols are discussed.
\end{abstract}

Keywords: Mexico, Miocene, continental lithostratigraphy, depositional systems, tectono-sedimentary evolution, paleosols.

\section{Resumen}

La discriminación y descripción de los sistemas deposicionales registrados en unidades litoestratigráficas de nuestro pais, es prácticamente una tarea pendiente de la Geología Mexicana, a pesar de su evidente importancia académica y práctica en la investigación de recursos minerales y acuiferos. Como una contribución para subsanar esta deficiencia, se describen y caracterizan los sistemas deposicionales de la Formación tardimiocénica San Nicolás, la cual constituye el relleno sedimentario principal del 
Graben Peotillos-Tolentino.

El área de estudio se ubica en San Luis Potosí, dentro de la Provincia Morfotectónica Sierra Madre Oriental [SMO], entre 22 ${ }^{\circ}$ $11^{\prime}$ - $22^{\circ} 19^{\prime}$ Latitud Norte, $100^{\circ} 30^{\prime}-100^{\circ} 39^{\prime}$ Longitud Oeste, y una Altitud de 1295 - 2025 msnm. Dicha formación es una gruesa secuencia $\left[\sim 1100 \mathrm{~m}\right.$ ] fluviolacustre, principalmente calcilititica, peneplaneada, e inclinada $15^{\circ}-20^{\circ}$ al $N E$, que discordantemente subyace un manto [espesor $40 \mathrm{~m}$ ] cuaternario calcilutítico-volcarenítico localmente cubierto por mafititas lávicas y/o piroclásticas.

La Formación San Nicolás incluye estos sistemas deposicionales: fluvial, lacustre, flujo de escombros y piroclástico [los dos últimos son volumétricamente poco significativos]. El primero consiste de las litofacies: (1) Gm, Gh, Gp: Depósitos de fondo. (2) Gm, $\mathrm{Gp}$, Sp, St: Barras de varias clases. (3) Sr, Sl, Fl: Depósitos de planicie de inundación; portan la fauna y palinoflora tardimiocénicas Paso del Águila, indicativas de bosque de pino-encino [de sotobosque bien desarrollado] y sabana, así como de clima más húmedo que el actual. (4) Gh, Sp: Depósitos conglomeráticos y/o arenosos delgados de canal. (5) Sl, Fl: Depósitos de ribera. (6) Sp, Sr, F1: Depósitos de bordo de ruptura. Paleosuelos [asociados a depósitos de planicie de inundación]: Fluvisol, Calcisol, Gleysol y Luvisol. El sistema lacustre incluye estas litofacies: (1 y 2) Carbonatos y finoclásticos lacustres, (3) finoclásticos de ribera, y (4) planicies de lodo. El flujo de escombros incluye las litofacies Gms y Sm.

El gran espesor de la Formación San Nicolás registra la sobreposición cíclica de sistemas deposicionales ocurrida en una cuenca subsidente pari pasu con la acumulación sedimentaria, bajo condiciones húmedas a subhúmedas, interrumpidas por otras de sequía [estacional?]. Finalmente se discute el usar taxa vegetales como indicadores paleoaltitudinales, y el descubrimiento de paleosuelos prepleistocénicos.

Palabras clave: México, Mioceno, litoestratigrafia continental, sistemas deposicionales, evolución tectono-sedimentaria, paleosuelos.

\section{Introduction}

After nearly thirteen decades of professional geologic research in Mexico, important tasks have been barely touched, such as the discrimination and characterization of the depositional systems registered in the formal lithostratigraphic units of this country, in spite of its importance on the investigation of placer mineral deposits and of aquifers. Thus, as a contribution to start filling this gap, here we present our first approximation to discriminating and characterizing the depositional systems of the San Nicolás Formation, Late Miocene of San Luis Potosí [Figures 1-2], the major sedimentary fill component of the Peotillos-Tolentino Graben; such endeavor pioneers this kind of research in the Cenozoic of the Sierra Madre Oriental Morphotectonic Province.

\section{Material and Methods}

The material used include: (a) Maps: INEGI (2005a-b; both are topographic). Geologic maps of the San Nicolás Tolentino Area scale 1:50000 [Figure 2]. (b) Equipment: Stereoscope Gordon Enterprises, Model Condor T22, num. 11248, Tokyo, Japan. Petrographic Microscope Olympus Optical, Model BX60F5 with Digital Camera Olympus, Model DP12-2. GPS Garmin, Model GPSMAP 62sc. Digital Camera Canon, Model EOS Digital Rebel XTi. Photomicroscope Zeiss.

The geologic work was done following standard procedures applied to discriminating and describing fluvial and lake deposits. Field work was conducted in two fourweek season during 2011 and 2012, and consisted of taking detailed photographs of the outcrops, tracing profiles, investigating bounding surfaces, traversing the outcrops to recognize and describe lithofacies, and making preliminary integrations to detect/interpret channel patterns. Positioning was done with a GPS, and measurements with a $50 \mathrm{~m}$ steel tape. Cartographic plotting was done directly on the topographic or geologic maps as we saw fit. The sedimentary petrographic nomenclature is largely that of Folk (1974) and Boggs (2009), the pyroclastic terminology is that of Schmid (1981), and Fisher and Schmincke (1984).

Facies recognition and description follows Miall (2006). Depositional systems attributes were described largely after Collinson (1996) and Miall (2006 and 2010). The architectural elements acronyms used are those proposed by Miall (2006): CH, Channel. LA, Lateral accretion. SG, Sediment gravity flow. GB, Gravel bar and bed form. DA, downstream accretion. SB, Sand bed form. LS, laminated sand. FF, overbank fines. Depositional systems modeling was done parsimoniously integrating all pertinent information [i.e., recognition and discrimination of depositional systems and their lithofacies, location, description and photographic illustration of specific outcrops, plotting and spatial association of similar systems and/or lithofacies on a topographic base map, and filling of gaps assuming continuation of nearest features/data]; such integration then, largely follows the methodology suggested by the latter author to work out the stratigraphic architecture of clastic deposits [Miall (2006)]; however, the limited objective data base warrants only a first [rough] approximation. Soil nomenclature is that of WRB (2006). Bed thickness was described following Ingram (1954). The palynologic analysis was performed using standard techniques [ $c f$. Batten (1999)], which are briefly described below:

- (a) In an iron mortar the rock is crushed to small 

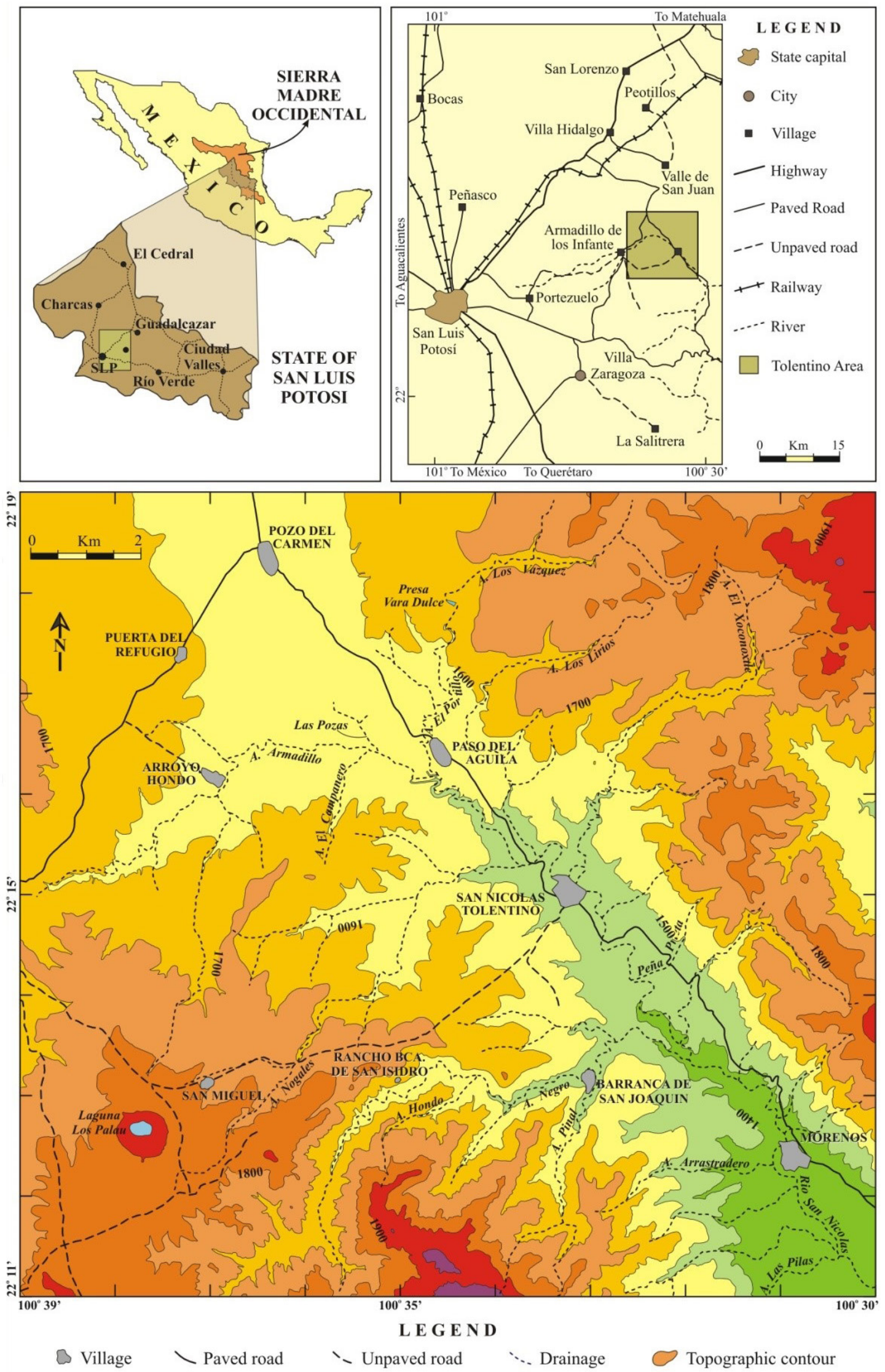

Figure 1. Index-map showing the location of San Nicolás Tolentino Area, central western Sierra Madre Occidental Morphotectonic Province at San Luis Potosí, México; all geographic features and names referred to in the text are plotted. 

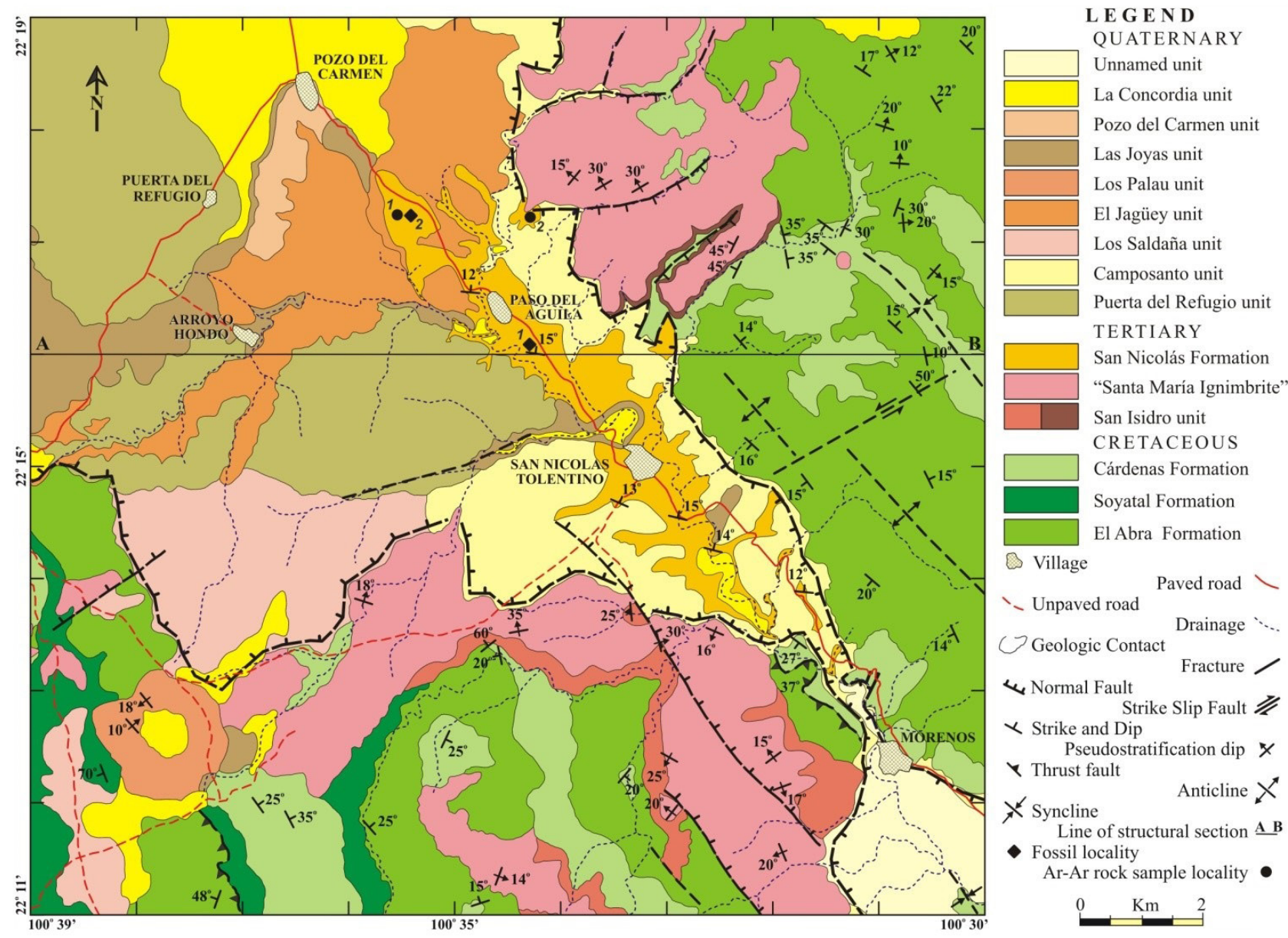

Figure 2. Geologic map of the San Nicolás Tolentino Area, central-western San Luis Potosí, México.

pieces [i.e., particle diameter $\sim 5 \mathrm{~mm}$ ], prior to their immersion in a beaker with an aqueous solution of $\mathrm{HCl}$ at $10 \%$ to eliminate carbonates.

- (b) Wash and neutralize the solid residue with distilled water, repeat the process several times.

- (c) Dissolve silica with HF (40\%).

- (d) Separate/eliminate any remaining mineral detritus from the organic residue (kerogene and palynomorphs) using a heavy liquid, such as sodium polytungstate.

- (e) The organic residue is treated with an acetolytic mixture in order to remove unwanted organic debris from the sample.

- (f) Finally, the remaining residue is washed with destilled water five times, after which it is ready to prepare the palynological slides using hydroxyethyl-cellulose as mountain medium.

The pollen and spores were identified and photographed with a photomicroscope, using higher magnification X100, and an oil-immersion objective.

\section{Results and Discussion: Depositional systems of the San Nicolás Formation, a first approach]}

\subsection{Initial Remarks}

This subject was briefly addressed in FerrusquíaVillafranca et al. (2011-b) and now it is discussed at length. Preceding information indicates that the San Nicolás Formation includes these systems: Fluvial, which makes the bulk of the unit; lacustrine, restricted to a small plain in the area's northwestern part; debris flow, only of local extent; and pyroclastic, which is also volumetrically very small [Figure 3]. However, the extensive Quaternary clastic cover of such unit, which actually crops out only on the cliffs carved by Río San Nicolás and tributaries [including the badland area located $\sim 2 \mathrm{~km} \mathrm{NW}$ of Paso del Águila] causes a paucity of suitable outcrops to attempt a full study of its depositional systems.

Under these conditions, we present only a first approach to discriminating, mapping and describing/discussing such systems, which of necessity, precludes a detailed description of the fluvial sequence in terms of: (a) channel stacking 

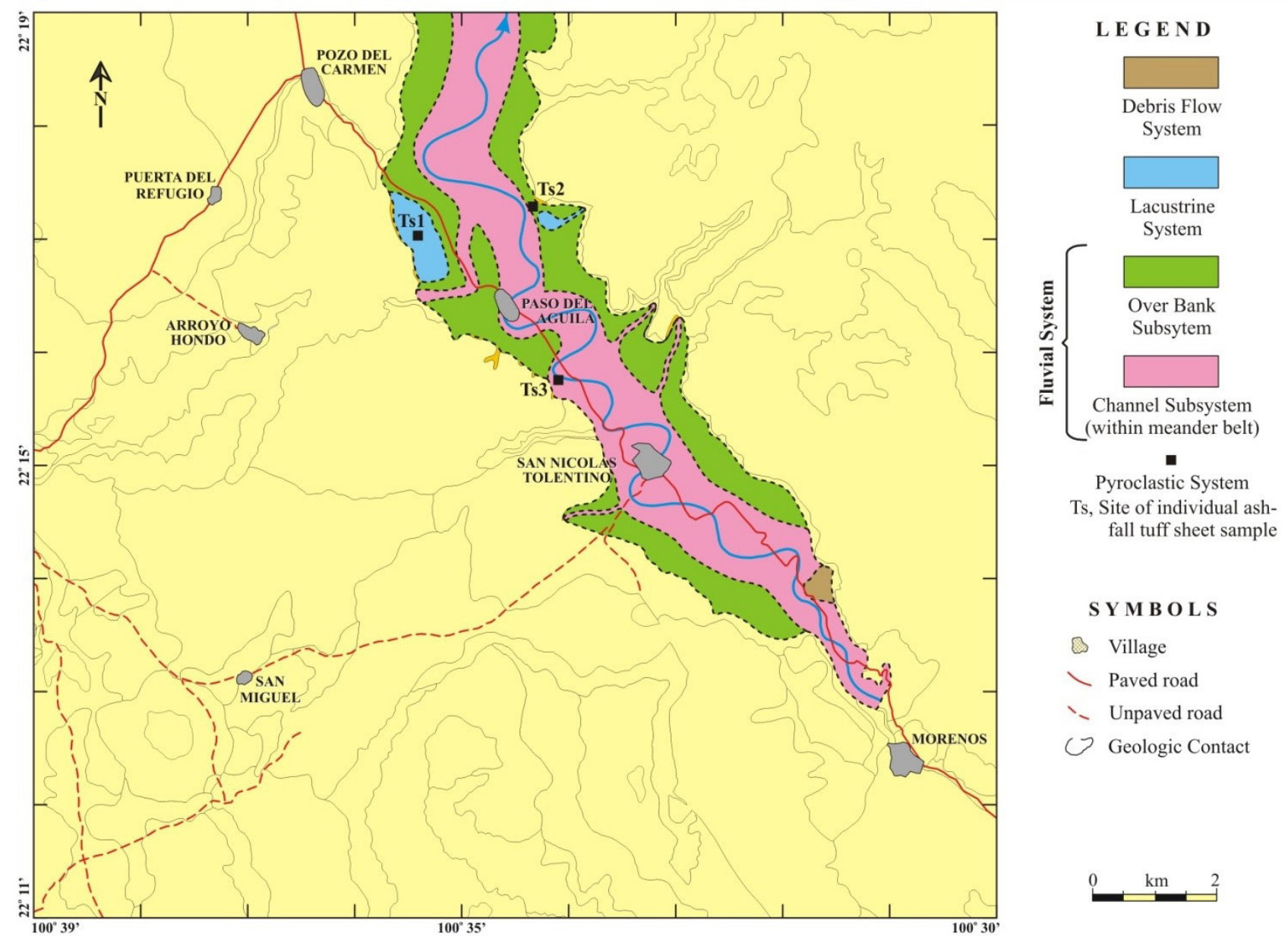

Figure 3. San Nicolás Formation's depositional systems model: First approach. The systems are plotted and discriminated within this formation area as mapped in Figure 2 [the geologic contacts are shown in the background]. In order to better portray the systems' aereal extent, the San Nicolás outcrop area was slightly increased, through parsimoniously uniting discontinuous San Nicolás outcrops [at the expense of adjacent Quaternary units].

patterns, (b) bounding surface hierarchies, (c) paleocurrent direction-populations, and (d) paleosol types and maturity. Consequently, our assessment of accretionary mechanisms, channel type(s), channel behavior, floodplain drainage conditions, and role of external controls [tectonics, base level, climate], is only approximate and tentative. Regarding the latter, mammals and palynomorphs afforded independent corroborative evidence. The description/discussion of depositional systems follows.

\subsection{Fluvial System}

Both channel and overbank facies-associations make up this system, however the first is better exposed, yet we strived to present a balanced view of both. The channel facies-association is described/discussed first.

\subsubsection{Gm, Gh, Gp Lithofacies: Channel lag deposits}

These deposits include the $\mathrm{CH}$ architectural element, and consist of clast-supported conglomerate, and granule- to coarse-sandstone set in medium to thick, ill-defined strata, showing concave up erosional bottom surfaces [third order bounding surfaces]; the lentoid form was readily discerned [Figure 4A], but other common deposit shapes such as blankets or strings, were difficult to make out due the scarcity of appropriate outcrops. Only in an outcrop south but near San Nicolás Tolentino, the lateral relationships through intertonguing with channel sandstone tabular bodies [a few meters thick] were observed. It should be noted that boulders, usually abundant in proximal bars, are not common here. This subject is further addressed elsewhere [see Concluding remarks on the depositional systems].

\subsubsection{Gm, Gp, Sp, St Lithofacies: Bars deposits of various types}

These deposits include the GB architectural element, and consist of clast-supported, sand-matrixed, pebble to cobble conglomerate set in thick strata [although mediumly ones are also common] showing faint to well developed crossbedding, largely forming tabular bodies up to $4 \mathrm{~m}$ thick; in some, the base surface shows scour and fill features [Figures 4B-D and 5]. The conglomerate bodies regularly alternate with medium to coarse-grained sandstone to granule-gravel 

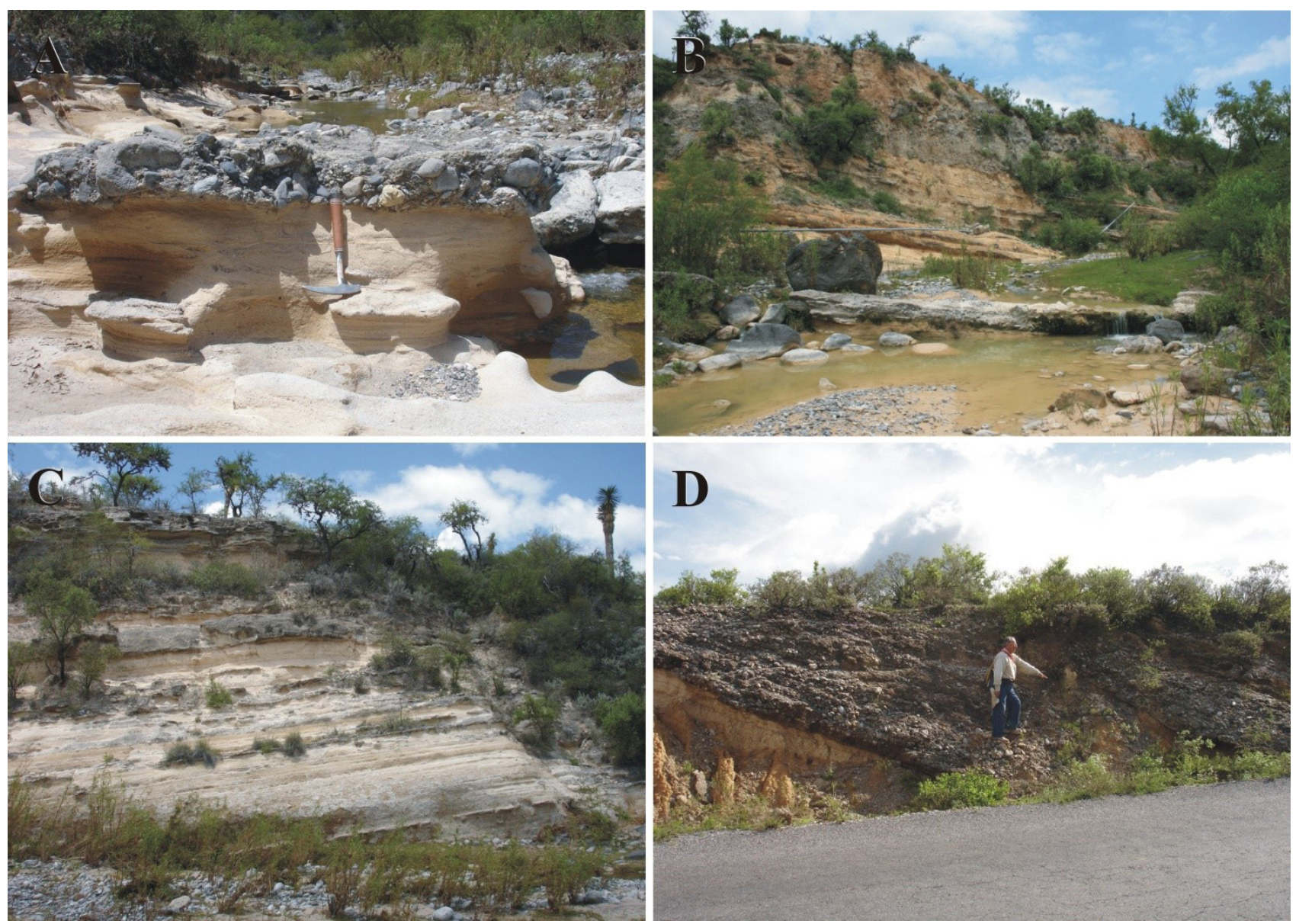

Figure 4. San Nicolás Formation's depositional systems, channel deposits I. A. Channel lag deposits: The site lies 1 km NE of Barranca de San Joaquín village, close to Arroyo Negro. Small conglomerate lens [lithofacies Gh] with flat-laying lower bounding surface, and a convex upper one interdigitated with tabular cross-bedded sandstone; this illustrates a downstream accretionary sequence, at a very reduced scale. East lies to the right of picture. B-D. Bar deposits: B. The locality lies on Río San Nicolás, $3.6 \mathrm{~km} \mathrm{NW}$ of Barranca de San Joaquín village. Section of a "large scale" point bar [chiefly lithofacies Gmg, Gh, Sp; and GB, SB architectural elements] showing in the bottom a flat-laying, medium-bedded conglomerate sheet supporting an alternate succession of tabular cross-bedded sandstone set in thin to medium strata, and thin conglomerate strata, followed upward by a thick conglomeratic body above, which records a new channel developed on top of the bar. Cliff height is $\sim 18 \mathrm{~m}$. North lies to the right of picture. C. The site lies $\sim 0.1 \mathrm{~km}$ SSE of San Andrés Tolentino. Thick succession of tabular cross-bedded channel sandstone [largely lithofacies Sp and subordinately Gp; and SB architectural element], within a sand-dominated (fluvial) system. The outstanding, ridge-like beds are better indurated than the others; some strata [e.g. those of the upper part] show large nodules [or concretions] seemingly consisting of darker, more indurated sandstone. Succession thickness $\sim 12 \mathrm{~m}$. North lies to the left of picture. D. Succession of thick sandstone and conglomerate bodies dipping $25^{\circ} \mathrm{NE}$ [mainly lithofacies Gh, Sp; and GB and SB architectural elements] showing flat bottom-bounding surfaces, a feature commonly seen in downstream accretion sequences; the succession is interpreted as part of mid-channel bars developing on top of another one. North lies to the right of picture.

conglomerate set in medium to thick strata, which show planar to trough cross-bedding, and usually form tabular channel sandstone bodies up to $6 \mathrm{~m}$ thick. These features allow us to interpret this sequence as consisting of compound bar deposits. Further positive bar type identification [as mid-channel, point bar, or other types, $c f$. Miall, 1987] is prevented for the scarcity of adequate outcrops. In those near Paso del Águila [ $c f$. Part 1, Principal Reference Section, this issue], the conglomerate and sandstone bodies that make up the succession are much thinner [>2 m], the conglomerate beds are commonly $1 / 4$ to $1 / 6$ as thick as the sandstone beds. Such succession is interpreted as the head of elongated midchannel bars. In other outcrops, the alternation is similar, but the sandstone bodies have flat erosional basal surfaces, which are suggestive of restricted lateral accretion of point bars in a meandering channel [Collinson (1996), Miall (2006)] As mentioned earlier, in the outcrop south of San Nicolás Tolentino Village, the intertonguing and superposition of conglomerate and sandstone channel bodies is well displayed, giving a glance to the complex depositional architecture of the San Nicolás Formation. Finally, it should be noted that boulder- or block-dominated conglomerates [usually interpreted as source-area nearness indicators], are not common; the possible significance of this fact is addressed at the end of this section].

The discrimination and positive recognition of other architectural elements commonly associated to fluvial channel conglomerate and sandstone bodies, such as 


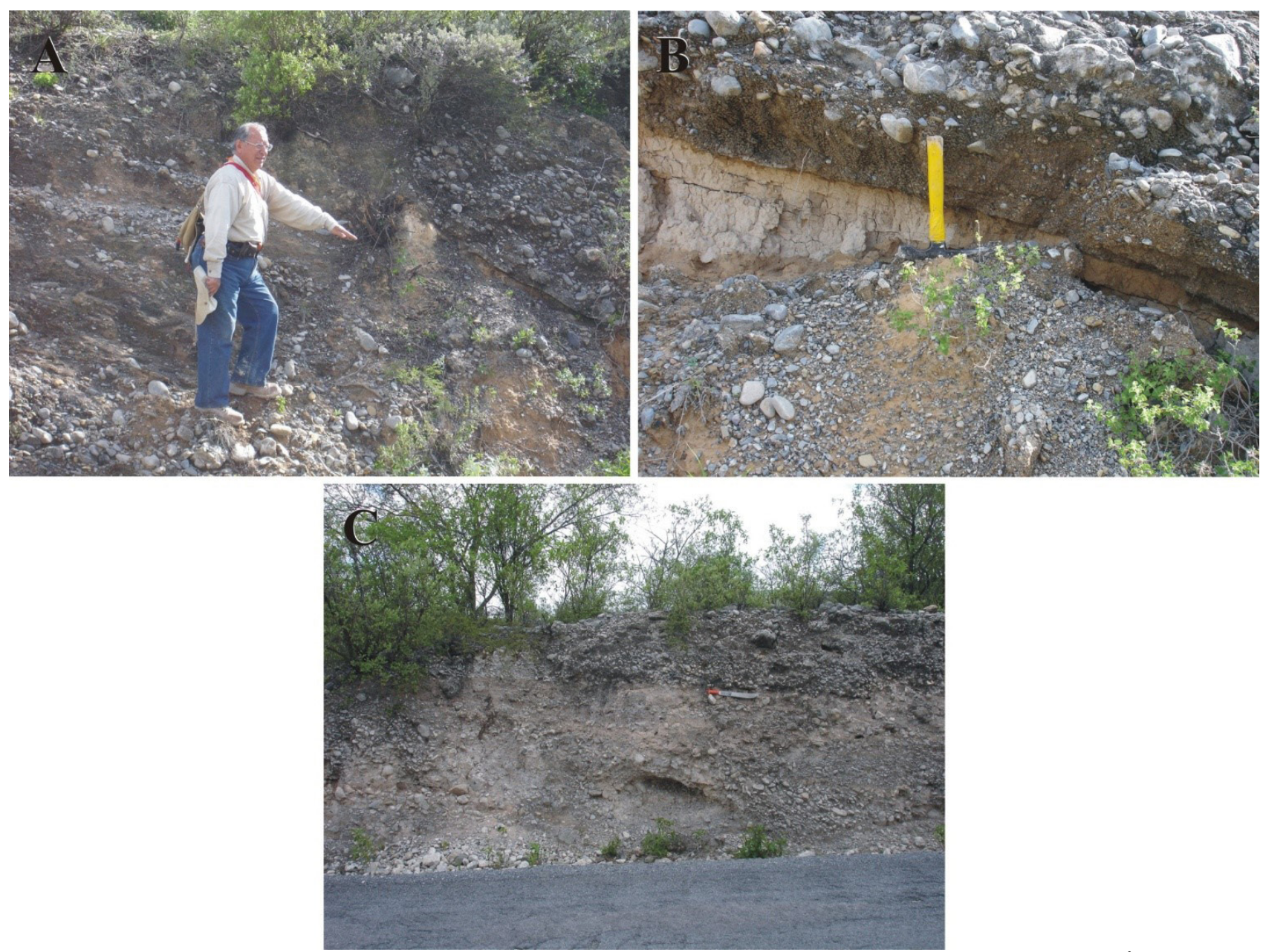

Figure 5. Nicolás Formation's depositional systems, channel deposits II. A-B. The site lies by Río San Nicolás $~ 800 \mathrm{~m}$ SE of Paso del Águila. A. Close view of same outcrop pictured in Figure 4D; the thick conglomerate strata show a vaguely defined horizontal bedding structure; notice the well developed bottom bounding surfaces. North lies to the right of picture. B. Closer view of same outcrop, notice the contact sharpness. North lies to the right of picture. C. The site lies $\sim 2.6 \mathrm{~km} \mathrm{NW}$ of Morenos, by the road to San Nicolás Tolentino. It shows sandstone and conglomerate intertonguing bodies [lithofacies Gh, $\mathrm{Sp}, \mathrm{Sl}$; and GB, SB architectural elements], which suggest that they belonged to a mid-channel bar seemingly developed in a gravel-dominated system (or subsystem). Road cut height $\sim 3.3 \mathrm{~m}$. North lies to the right of picture.

downstream accretion [DA element] or lateral accretion [LA element] deposits [cf. Ramos and Sopeña (1983), Miall (2006)], usually requires a three dimensional architectural analysis [Miall (op. cit.)], which depends on the existence of adequate and more extensive outcrops than those available in the study area. Therefore, such elements/deposits were very tentatively identified. Sandstone units with imbricated clasts seemingly dipping west [i.e., normal to the northnorthwest paleoflow direction inferred from the local and regional tectonic setting], were interpreted as recording lateral accretion. On the other hand, the alluvial fan facies seems not to be exposed in the study area. However, deposits consisting of medium to coarse sandstone set in thin to medium strata interbedded by thin conglomerate beds may represent distal fan facies. Further, preliminary provenance studies in the San Nicolás Formation suggest that the chief source-area was located in the south, thus probable the best part of the alluvial fan facies was laid down in the basin's southern (initial) part, and that later on, it was partly covered by other fluvial facies, and subsequently by the extensive Quaternary deposits of the area. Now, let us deal with the overbank facies-association of the San Nicolás Formation.

\subsubsection{Sr, Sl, Fl Lithofacies: Floodplain deposits}

These deposits include the FF architectural element, and are best exposed in the northern part of the area, where badlands have developed. The floodplain lithofacies association [Figure 6] usually consists of friable to slightly indurated (calcitic) claystone, clayey siltstone and fine- to medium grained, calcilithitic sandstone showing laminar cross-bedding to low angle planar cross-bedding; they are set in laminar to thin strata which may form monotonous stacks up to $1.2 \mathrm{~m}$ thick, intercalated by better indurated, ridge-forming siltstone or sandstone beds [ $>0.4 \mathrm{~m}$ thick]. The badlands geomorph makes difficult to perceive the sheet-like morphology of this kind of deposits. The 
presence of calcite nodules detected in a few places [see Part 1, Figures 14E-F and 15A-B; this issue], indicates that the floodplain was exposed to subaereal conditions, so that pedogenetic processes were taking place there. In fact, typical floodplain sedimentary structures, such as lamination/very thin bedding and low angle laminar/tabular
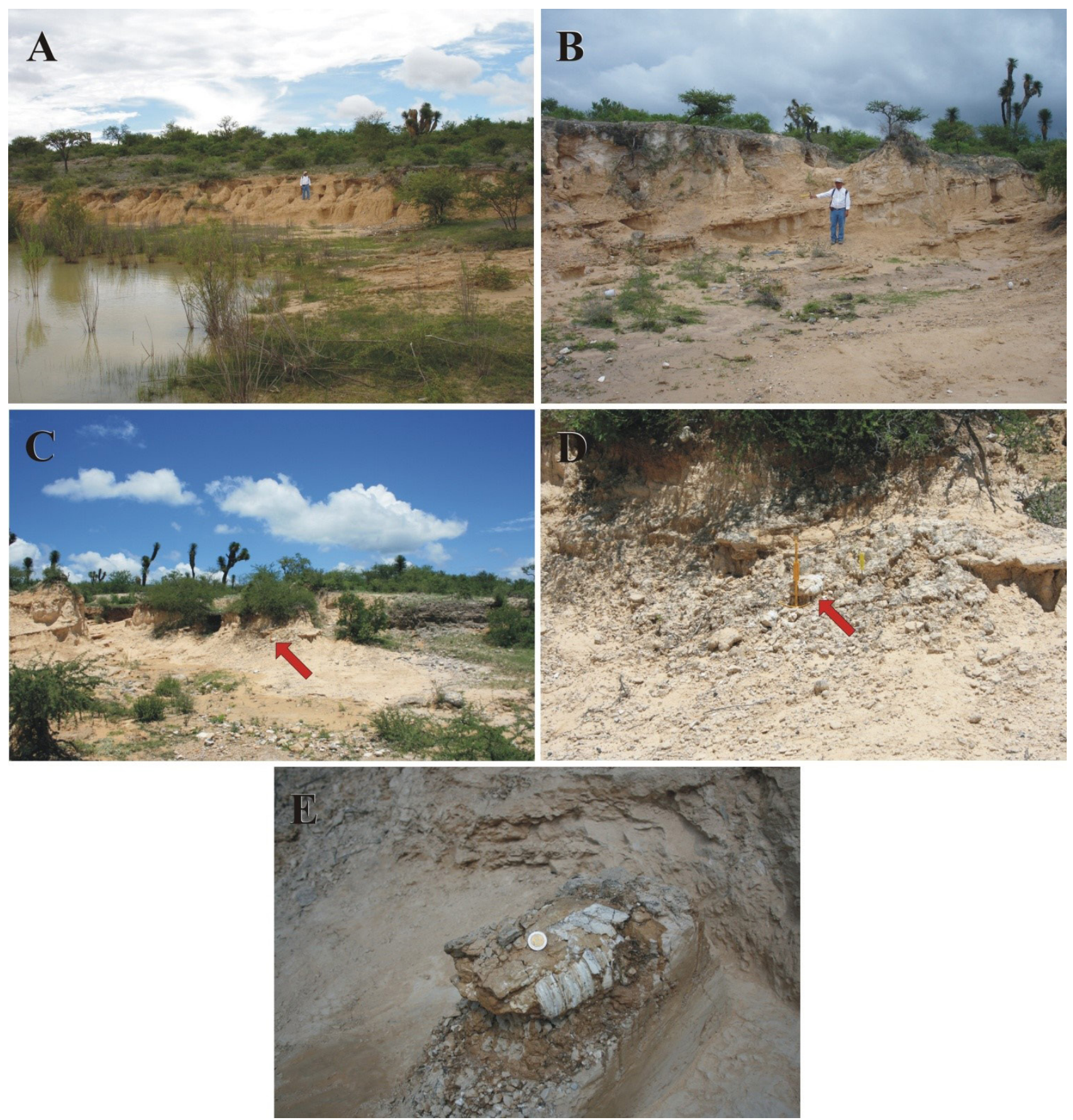

Figure 6. San Nicolás Formation's depositional systems, overbank deposits I, Floodplain deposits. A. The site lies $\sim 1$ km nearly due South of Paso del Águila: Floodplain deposits [largely lithofacies Fl, Fm; and FF architectural element] are commonly seen in the badlands geomorph, as in this outcrop, where in the lower part, bedding is still discernible, whereas in the upper one [man standing there], paleosols [Luvisols] have erased it. Outcrop height $\sim 3.8 \mathrm{~m}$. North lies to the left of picture. B-E. The locality lies $\sim 0.75 \mathrm{~km}$ ESE of Paso del Águila: B. Alternation of thin to medium bedded, fine-grained sandstone and thinly bedded clayey siltstone; the "thick" sandstone bed might be a crevasse splay deposit; the Quaternary Camposanto unit [conglomerate facies] unconformably overlies the floodplain deposits. North lies to the left of picture. C. Same alternation as above, the arrow points to a fossil horse skull. The cliff's height [picture's left hand side] is $\sim 4 \mathrm{~m}$. North lies to the left of picture. D. A fossil horse skull [pointed by arrow] weathering out of floodplain strata, the loose gravel around it was eroded from the Camposanto unit. East lies to the right of picture. E. Fossil-bearing floodplain sequence consisting of alternating friable, fine-grained clayey sandstone and siltstone set in thin strata [which individually show laminar cross-bedding]; the horse skull lies on a pedestal and is ready for bandaging and removal [coin's diameter $=20 \mathrm{~mm}$ ]. East lies to the right of picture. 
cross bedding were not frequently observed, while thick, structureless zones were common, thus indicating that the fine-grained floodplain strata were readily transformed under humid, stable conditions into paleosols [largely luvisols, see Paleosols below].

On the other hand, a small but significant mammal assemblage [Paso del Águila local fauna, see Part 1, Table 1; this issue], was recovered from floodplain strata in localities near the namesake village, which preliminarily allows us to date both fauna and bearing unit as of Late Miocene age [Ferrusquía-Villafranca et al. (2014)], a datum congruent with the volcanic glass ${ }^{39} \mathrm{Ar}-{ }^{40} \mathrm{Ar}$ ages determined from tuff sheets of this formation [see Part 1, Table 1; this issue]; however, the assignment remains tentative, because the ${ }^{39} \mathrm{Ar}-{ }^{40} \mathrm{Ar}$ evidence is not conclusive [see Part 1, Age and Correlation; this issue].

In addition, a pollen assemblage was recovered too from this lithofacies in several localities [San Nicolás Palynoflora, Table 1 and Figures 7-8], the taxa largely belong to a temperate mesophyllous vegetation [e.g. Quercus sp., Betula, Corylus], and to a mesophyllous forest [e.g. Momipites (Engerhardtia) and Alnipollinites (Alnus sp.), and ferns (e.g. Polypodium)]; such vegetation types probably occupy lowlands, whereas other taxa such as Pinus and Liquidambar inhabited the surrounding mountain slopes; the understory vegetation included Compositae and Graminea, which could also thrive in the lowlands making up a savanna. The climate disclosed by this palynologic assemblage is temperate to humid, much like the one occurring in present-day northern Chiapas [Los Altos de Chiapas], contrasting with the arid climate $[\mathrm{Cw}]$ prevailing nowdays [García (1990)].

It is well known that latitude and altitude exert a strong control on the distribution of both Recent and fossil floras [cf. Axelrod and Raven (1985), Barbour and Billings (1988 and lit. therein), Wijnga (1995), Tiffney and Manchester (2001)]; a comparison between the San Nicolás and Ixtapa palynofloras [Martínez-Hernández (1992)] bears this out. The latter chiefly consists of pantropical taxa, which are largely absent in the former flora. On this basis, it is hypothesized that the San Nicolás Palynoflora was deposited in a Miocene basin standing 2000 masl. This altitude largely corresponds to the present-day one, thus indicating that such altitudinal position was reached by Late Miocene time, and has remained so ever since.

\subsubsection{Gh, Sp Lithofacies: Thin channel conglomerate and/or sandstone deposits}

These deposits include the $\mathrm{CR}$ architectural element. The presence of small lenses of pebble to granule conglomerate and coarse sandstone showing horizontal to low angle cross-bedding, set on top of floodplain fines [Figure 9A$\mathrm{C}]$, is interpreted as channel lag deposition related to avulsion events that incised the levees/banks of "larger/ source" channels [up to then confined] deep enough to tap the gravel lag. Third order bounding surfaces separate both kinds of deposits.

\subsubsection{Sl, Fl Lithofacies: Levee deposits}

These deposits [Figure 9D] include the LV architectural element, and consist of very fine sand to mud that usually shows low angle, thinly tabular to laminar cross bedding set in thin beds forming stacks $>2 \mathrm{~m}$ thick; sand and mud strata seem to alternate. These deposits are not common, those observed lied near CR elements or were isolated in floodplain fines; they may correspond to levee deposits; however, their lack of ripple marks is not congruent with this interpretation [cf. Miall (2006)].

\subsubsection{Sp, Sr and Fl Lithofacies: Crevasse splay deposits}

These deposits include the CR and CS architectural elements, and consist of thin sheets of medium to coarse sandstone with low to very low planar cross-bedding, irregularly intercalated within typical floodplain finergrained sediments, probably represent crevasse splay deposits related to major flooding episodes. Small [>2 m thick] sheet-like bodies of very fine sandstone and silty claystone showing an internal structure of laminar- to very thin planar cross bedding, are also interpreted as crevasse splay deposits [Figure 10]. It should be noted that both kinds are not common. On the other hand, our interpretation as crevasse deposits is tentative, because to work out their lateral relationships, is severely hampered by the scarcity of adequate outcrops.

\subsubsection{Paleosols}

Floodplains are periodically exposed to subaerial conditions, whereby soils and a vegetation cover usually develop; if the former are buried during subsequent flooding episodes, become paleosols [with features diagnostically different from modern soils lying in the same area]. So exposed floodplain strata usually carry calcretes and root fillings, their finding prompted us to look more carefully for paleosols. Here we present only brief comments on paleosols, because a formal study of them would require a project by itself.

Something that called our attention was why in spite of the San Nicolás Fm. great thickness [ 1100 m at least], and that it records recurrent fluvial deposition [including frequent periods of floodplain subaerial exposures], the detection and recognition of its paleosols was so little productive. It appears that these facts hampered this endeavor: (a) Scarcity of outcrops. (b) Difficult access to adequate outcrops [e.g. some were cliffs, or steep slopes of badland gullies]. (c) Modern soils overprinting of true paleosols. Anyway, the following paleosols are briefly described/discussed.

Fluvisols. They are soils that have no discernible horizons, with the exception of some darkening of the surface [WRB (2006)]; a vague stratification is usually apparent. In the present instance [Figure 11A] the Fluvisols units are pink, moderately thick [50 to $60 \mathrm{~cm}$ ], and coarsely 
Table 1. Palynoflora of the San Nicolás Formation, Late Miocene of San Luis Potosí, México.

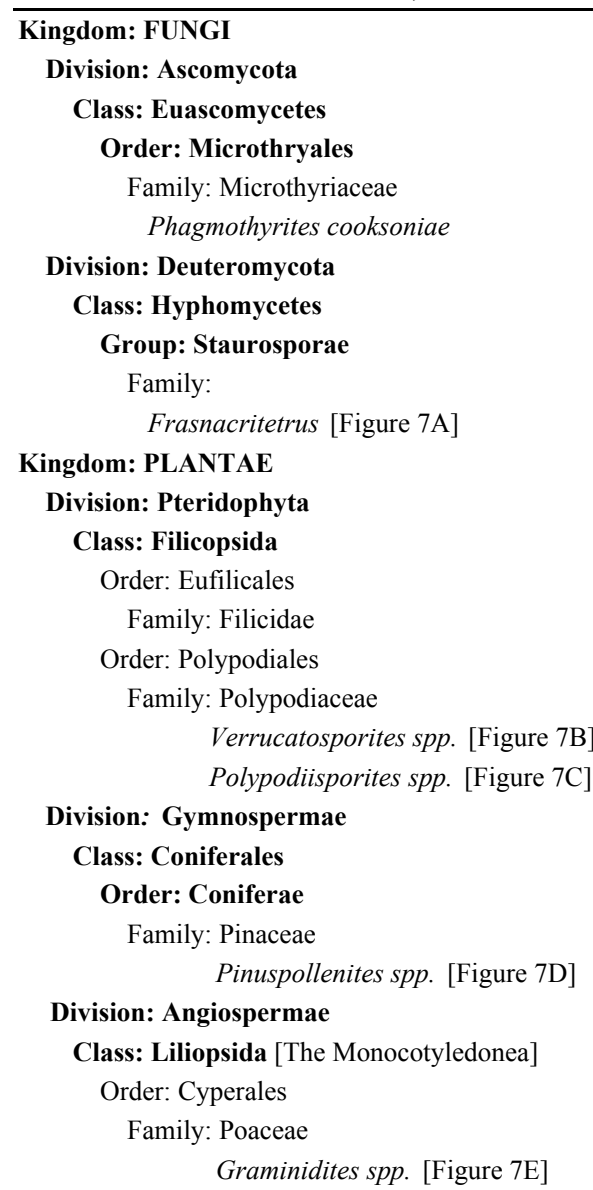

Class: Magnoliopsida [The Dicotyledonea]

Order: Hamamelidales

Family: Hamamelidaceae

Liquidambarpollenites spp. [Figure 7F]

Order: Fagales

Family: Fagaceae

Quercoidites spp. [Figure 7G]

Order: Betulales

Family: Betulaceae

Alnipollenites spp. [Figures $7 \mathrm{H}$ and $8 \mathrm{~A}$ ]

Trivestibulopollenites spp.

Triatriopollenites spp.

Triporopollenites spp. [Figure 8B and 8C]

Order: Juglandales

Family: Juglandaceae

Momipites spp.

Caryapollenites spp.

Order: Caryphyllales

Family: Chenopiaceae

Chenopodipollis spp . [Figure 8D]

Caryphyllales incertae sedis

Thomsonipollis ssp. [Figure 8E]

Order: Fabales

Family: Mimosaceae

Polyadopollenites spp. [Figure 8F]

Order: Asterales

Family: Asteraceae 

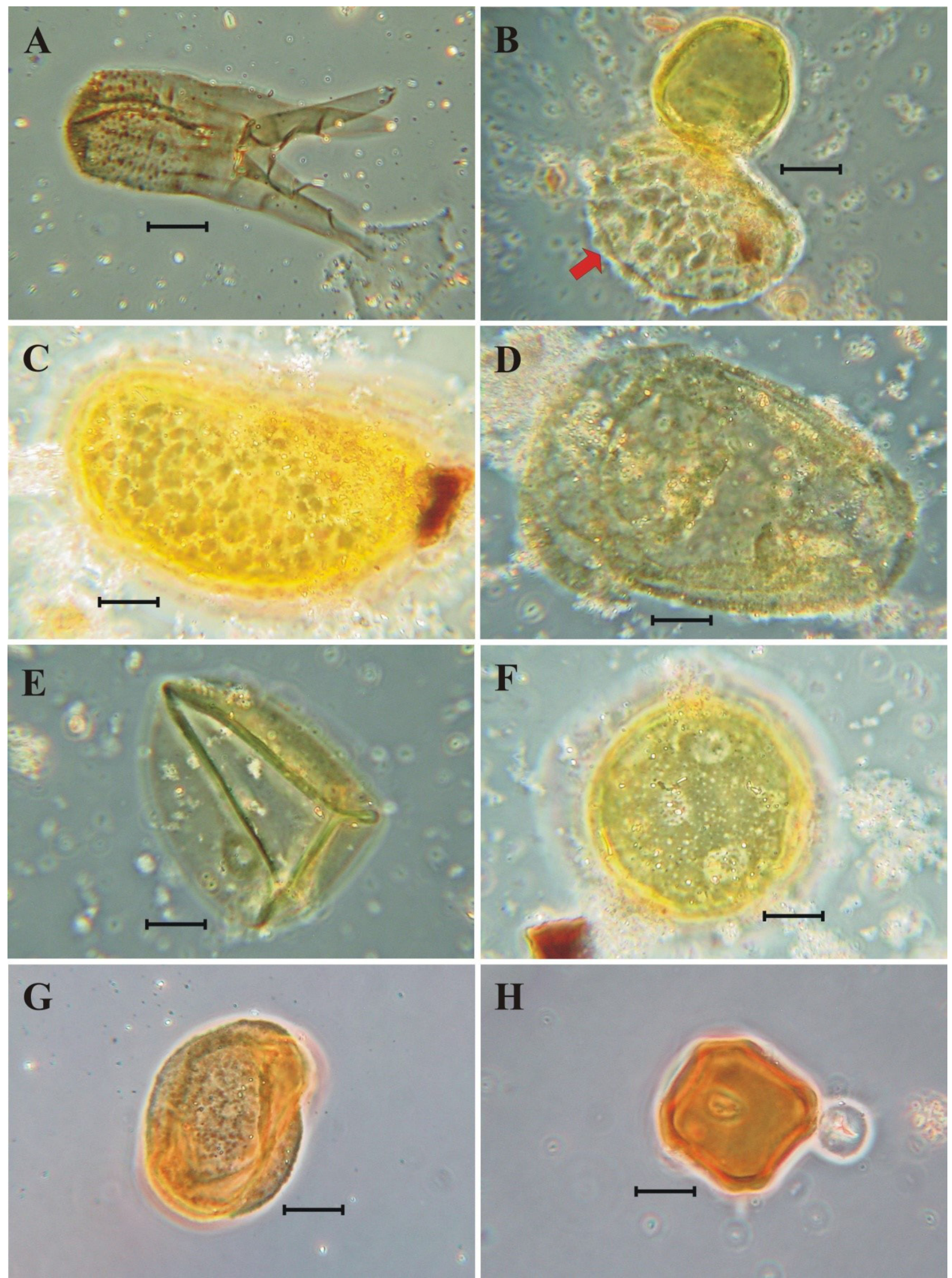

Figure 7. Palynoflora of the San Nicolás Formation I. [Photomicrographs taken using phase contrast microscopy; bar $=10 \mu \mathrm{m}$ ]. Ascomycota. Pteridophyta, Gymnospermae, Angiospermae: A. Frasnacritetrus. B. Verrucatosporites spp. [marked by an arrow]. C. Polypodiisporites spp. D. Pinuspollenites spp. E. Graminidites spp. F. Liquidambarpollenites spp. G. Quercoidites spp. H. Alnipollenites spp. 

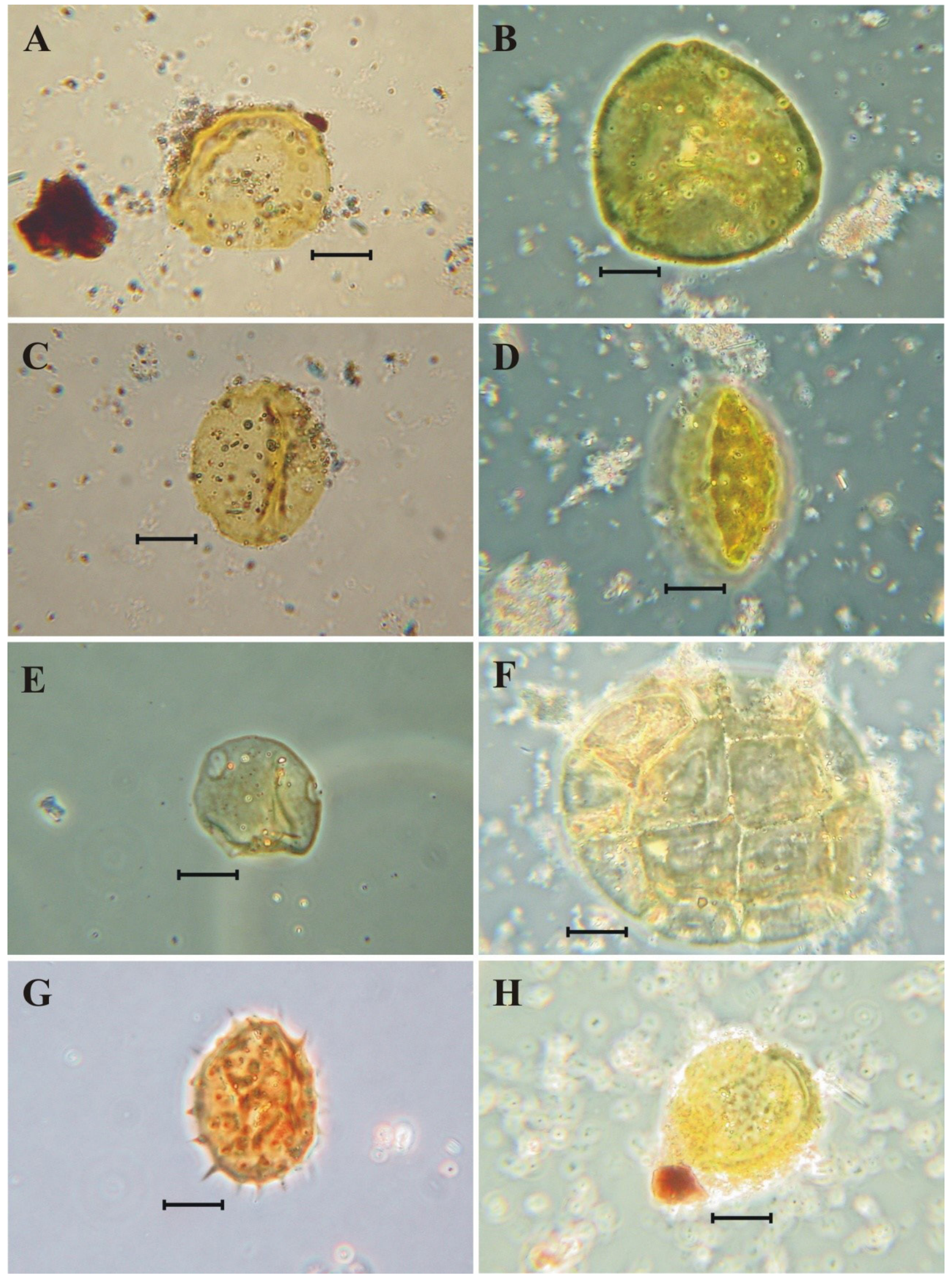

Figure 8. Palynoflora of the San Nicolás Formation II. [Photomicrographs taken using phase contrast microscopy; bar $=10 \mu \mathrm{m}]$. Angiospermae (continuation): A. Thomsonipollis. B. Triatriopollenites spp. C. Triporopollenites spp. D. Triporopollenites spp. E. Chenopodipollis spp. F. Polyadopollenites spp. G. Tubilifloridites spp. 1. H. Tubilifloridites spp. 2. 

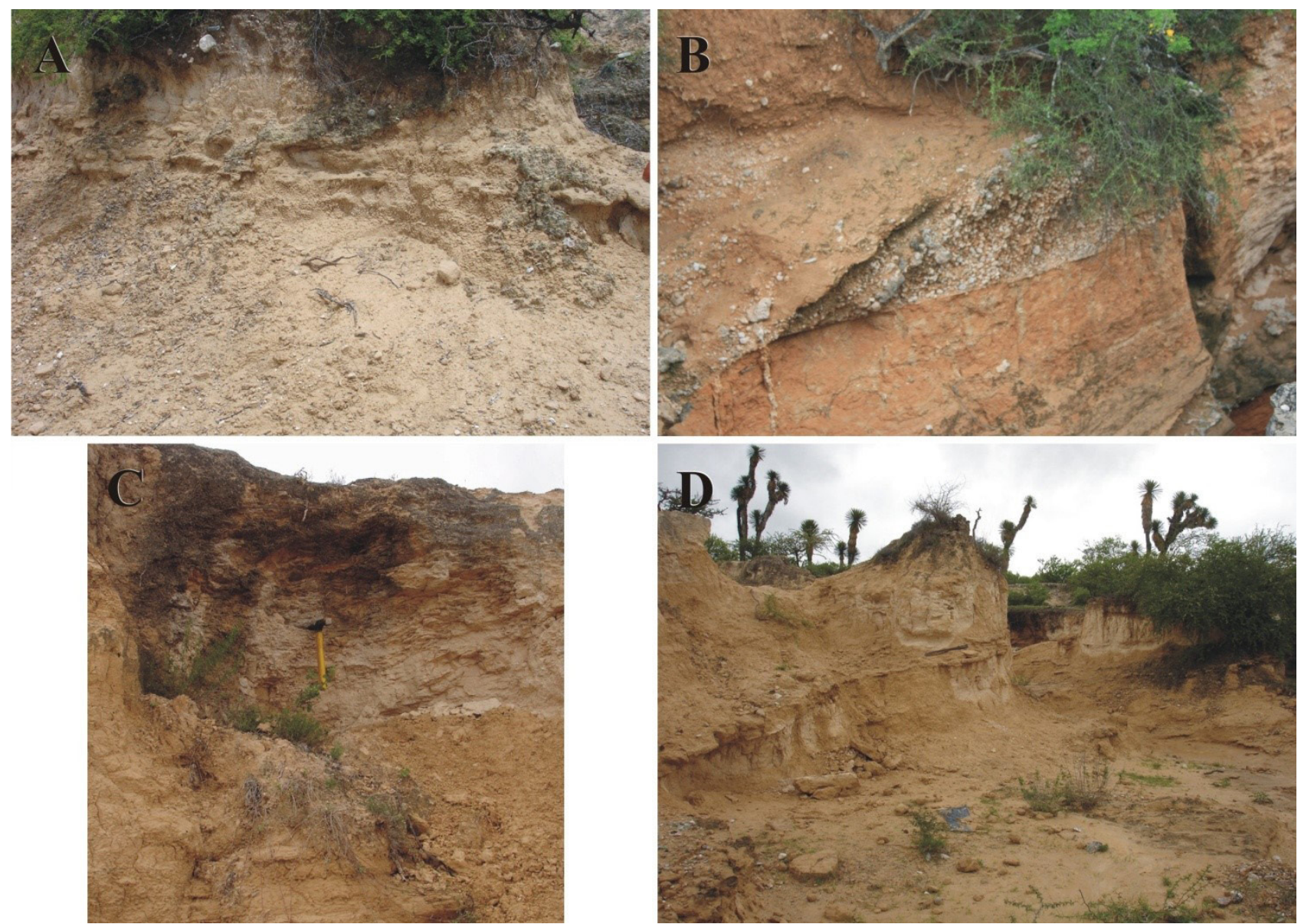

Figure 9. San Nicolás Formation's depositional systems, overbank deposits II. A-B. Thin channel conglomerate deposits: A. The site lies $\sim 2.3 \mathrm{~km}$ SE of Pozo del Carmen. The small, $0.8 \mathrm{~m}$ thick conglomerate lens [top right, lithofacies $\mathrm{Gh}$ ] records channel scouring/lag-filling on a floodplain deposit [lithofacies Fl; largely covered by loose sediments], related to a crevasse episode that tapped the main channel's lag, transporting/depositing it over the floodplain. East lies to the right of picture. B. The locality lies $\sim 2.3 \mathrm{~km} \mathrm{SSE}$ of San Nicolás Tolentino. Floodplain sequence [lithofacies Sm, Fl] intercalated in the middle by a small, well defined, $\sim 0.75 \mathrm{~m}$ thick gravel conglomerate lens [lithofacies $\mathrm{Gh}$ ] with smooth bounding surfaces; the sequence's lower half consists of whitish, fine-grained, low angle planar cross-bedded sandstone [bottom], and thinly bedded, red clayey siltstone [above], the upper half consists of red clayey siltstone sparsely interbedded by gravel; the conglomerate lens is interpreted as a thin channel conglomerate deposit that records a distinct crevassing episode, whereby the main channel's lag was partly transported/deposited on a floodplain, and was covered by suspended-load sediments of subsequent flooding episodes. North lies to the left of picture. C. Thin channel sandstone deposits: The site lies $\sim 0.7 \mathrm{~km}$ ESE of San Nicolás Tolentino. Small sandstone channel lens with "wings" [lithofacies Ss] developed/scoured-and-filled over a pre-existing floodplain deposit. Just below it, planar cross-bedded sandstone strata forming a thin sheet indicate previous overbank deposition [in a sand-dominated system?]. The cliff's height is $\sim 4 \mathrm{~m}$. North lies to the left of picture. D. Levee deposits: The locality lies $\sim 1.8 \mathrm{~km} \mathrm{SE}$ of San Nicolás Tolentino, somewhat north of Arroyo Peña Prieta. Sequence of very fine-grained, low angle cross-bedded sandstone set in thin beds forming 2 to $4 \mathrm{~m}$ thick stacks [lithofacies Sr, Fl; seemingly a small scale LV architectural element] lying on top of a strongly eroded, quite friable floodplain deposit [fines consists of thinly bedded clayey siltstone and silty claystone, clearly seen in the picture's right hand side]. North lies to the left of picture.

textured [gravel and sand clasts dominate]; the inherited stratification of a channel lag deposit is still discernible. It appears that a subsidiary channel developed during a crevassing episode, laid down a thin sheet of gravel lag on top of floodplain strata, which subsequently evolved to a Fluvisol [FAO-ISRIC-SICS (1998), WRB (2006)]. Figure 11B shows better developed Fluvisols.

Calcisols. They are soils with substantial secondary accumulation of lime, usually by the translocation of calcium carbonate from the surface horizon to an accumulation layer at some depth [calcrete], commonly occurring under semiarid conditions; they require a long time to develop [FAO-ISRIC-SICS (1998)]. Figure 11B also depicts pink, moderately thick [ $\sim 25$ to $50 \mathrm{~cm}]$, and finelytextured Calcisols with whitish zones; the B horizon seems well developed; in the upper part, numerous fibrous rootfillings are locally common; Figure $11 \mathrm{C}$ shows a sequence of Calcisols; usually, these soils are prone to compression by overburden [Figures 11B-C].

Gleysols. They are soils developed on topographic depressions with a shallow phreatic level, which in turn causes excessive wetness at shallow depths $[<50 \mathrm{~cm}$ from the soil surface] during part of the year [WRB (2006)]. Figure 11D illustrates a sequence of four paleosols, including a Gleysol unit; these soils were developed on the fined-grained floodplain sediments, and evidence recurrent 

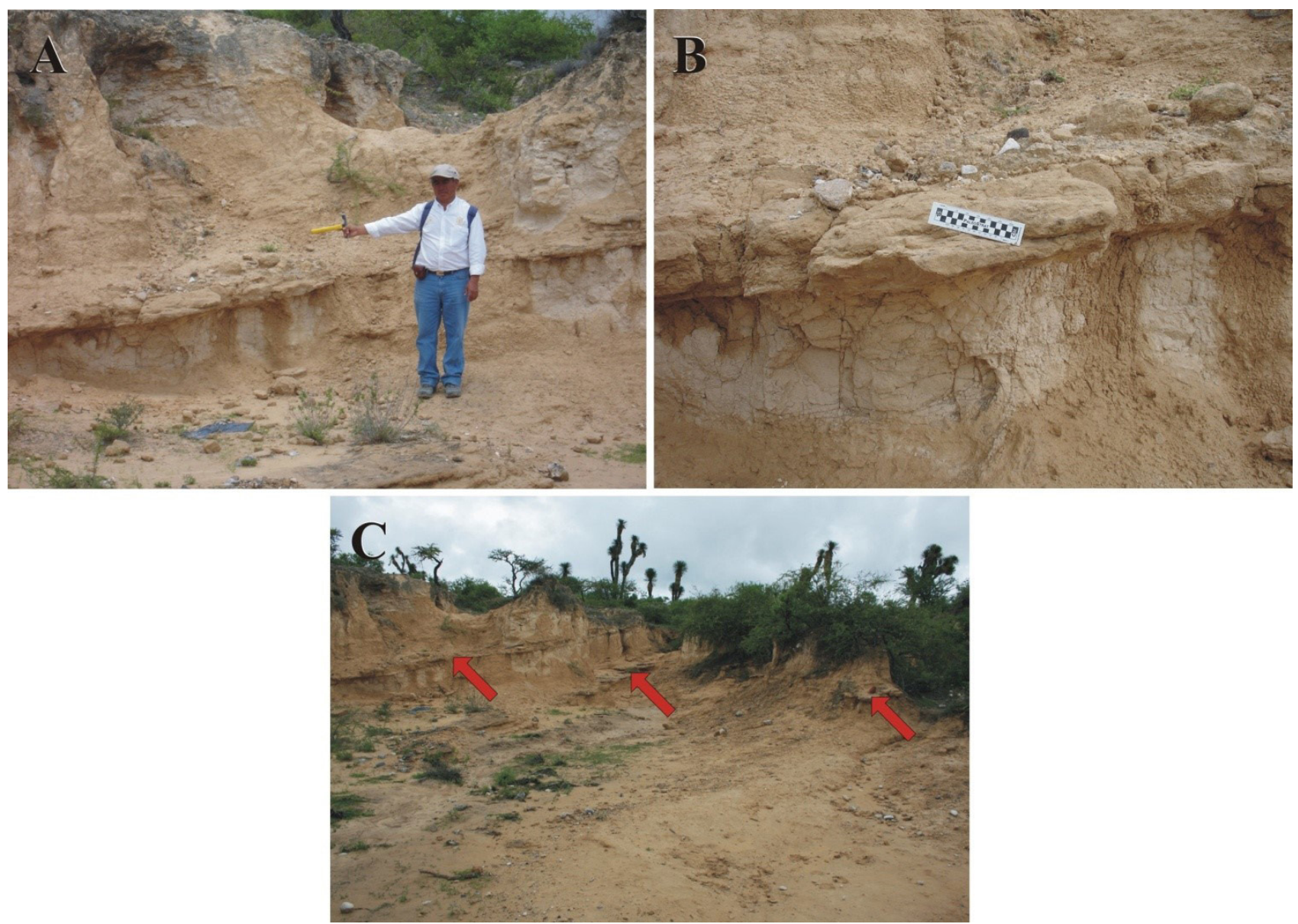

Figure 10. San Nicolás Formation’s depositional systems, overbank deposits III. A-C. Crevasse splay deposits: A. The site lies 2.6 km SE of San Nicolás Tolentino. A. Mediumly thick stratum of moderately indurated, ridge-forming, planar cross-bedded sandstone [lithofacies $\mathrm{Fl}$ ] interbeds a sequence of floodplain fines [friable clayey siltstone] indicating crevasse splay deposition of fine grained lag from the major channel over a floodplain body, followed by normal flooding deposition. North lies to the left of picture. B. Close view of same outcrop. Notice that the fine-grained sandstone splay sheet lies above a sandstone channel lens, which records a previous crevassing episode. North lies to the left of picture. C. The locality lies $\sim 2.4 \mathrm{~km}$ SE of San Nicolás Tolentino, near Arroyo La Tienda. Several thin sandstone sheets [lithofacies Fl pointed by arrows] interbed a $\sim 8 \mathrm{~m}$ thick floodplain sequence, indicating repeated crevasse splay deposition. North lies to the left of picture.

subaereal exposures.

Phaeozems. They are dark soils rich in organic matter [ $\sim 5 \%$ in the surface layer], and commonly occur on basic, fine-textured parent material, under more humid conditions than those of Calcisols [FAO-ISRIC-SICS (1998)], thus their rates of weathering and leaching of bases are higher than those in Calcisols and Fluvisols [WRB (2006)]. Figure 11D illustrates Phaeozems developed in the San Nicolás Formation.

Luvisols. They are soils bearing an illuviation horizon formed by translocation of clay from the surface soil to an accumulation horizon [zone] at some depth. Luvisols develop best in flat or gently sloping land in temperate regions, and in warm ones with distinct dry and wet seasons [WRB (2006)]; Luvisols are associated with long-term climatic and geomorphic stability. The Luvisols illustrated in Figure 11E are grayish orange, very thick [ $>3 \mathrm{~m}]$, finely textured [clay to fine silt], and geomorphically expressed as badlands. It is possible that the fine-grained texture of the floodplain deposits could have been particularly prone to evolve into Luvisols [FAO-ISRIC-SICS (1998), WRB (2006)].

The recognition of Luvisols as major constituents of badlands, is a long known fact [cf. Retallack (1983)], which has not been applied in Mexico either to badlands or paleosols studies. In fact, Luvisols had not been detected in Mexico's pre-Pleistocene paleosol record [FerrusquíaVillafranca et al. (2010)]; therefore, the recognition of Luvisols in the Late Miocene San Nicolás Fm., is a significant discovery.

Calcretes. There are calcareous nodules s.l. in some strata. Common calcrete features include [Arakel (1982)]: Carbonate replacement of silicic clasts and the gradation thereof [see Part 1, Figures 14E-F and 15A-B; this issue], carbonate interstitial space-filling, quartz corrosion, and preservation of sedimentary textures/structures as relicts. 

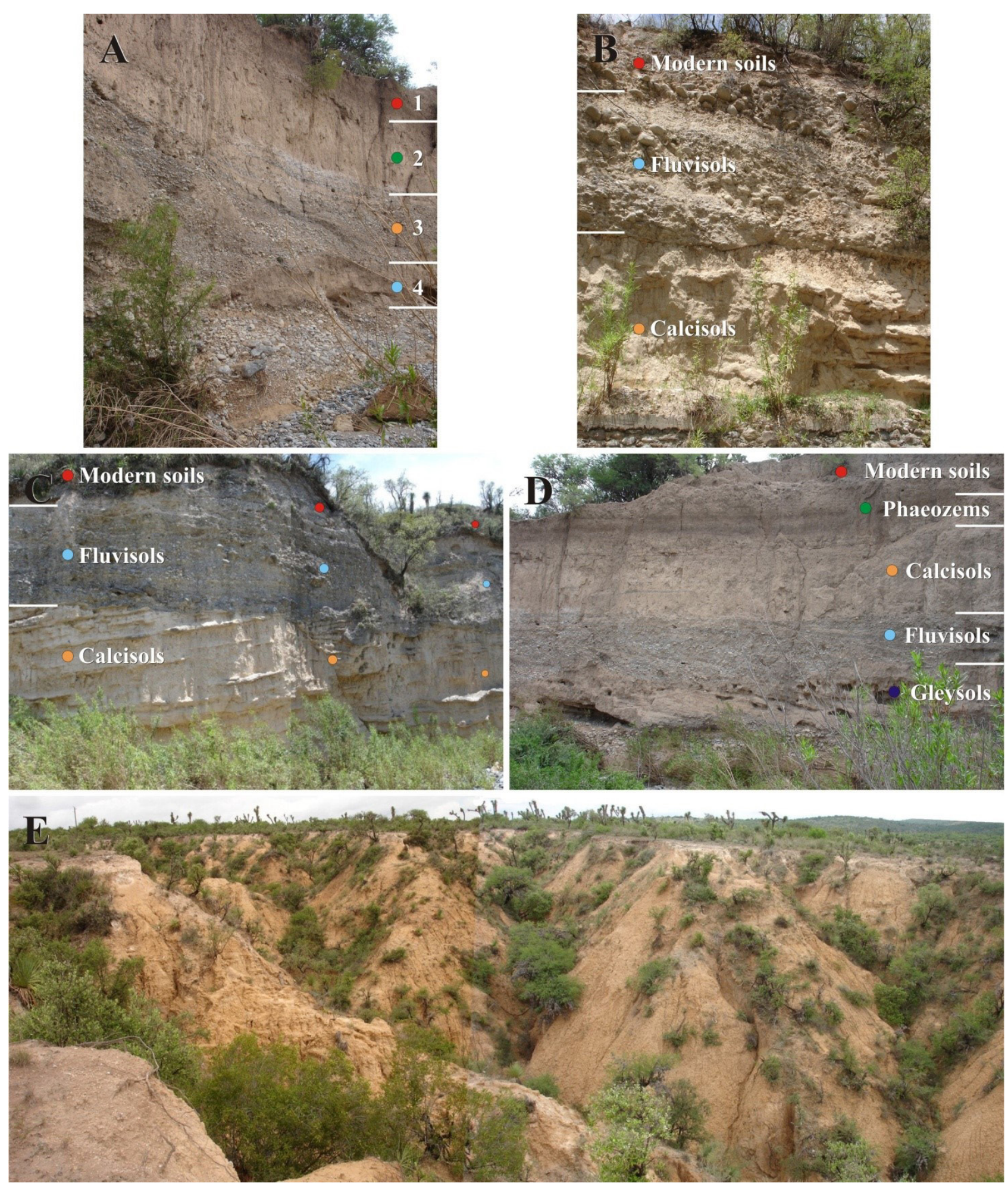

Figure 11. San Nicolás Formation's Paleosols. A-E. The localities are situated in the badlands area, which lies $\sim 1$ km due north of Paso del Águila: A. Paleosols units sequence developed under a subarid climate regime. 1. Modern soils. 2. Phaeozems. 3. Calcisols. 4. Fluvisols. East lies to the right of picture. B. Effects of burial diagenesis [compaction] on Calcisols. East lies to the right of picture. C. Rythmic Calcisols sequence developed in the floodplain fines, disclosing recurrent episods of subarid conditions in the area. The thick overburden [Quaternary Camposanto unit (conglomerate facies)] has diagenetically compressed the paleosols. East lies to the right of picture. D. A pedostratigraphic profile developed in the San Nicolás Formation showing a succession of Paleosol units capped by modern soils. East lies to the right of picture. E. The paleosols depicted, Luvisols, are geomorphically expressed as badlands, which in a few localities have yielded mammal remains. North lies to the left of picture. 
Both pedogenetic and phreatic processes may generate calcretes, hence a major goal of the study was to discriminate these two kinds. Only one sample was certainly identified as pedogenetic, because it has these features: (1) Alpha fabrics. (2) Fine-grained texture [including soft lime powder, clay, silt and very fine sand]. (3) Strong reaction to HCL. (4) Weak carbonate cementation (5) Traces of roots. This sample is best interpreted as part of a calcisol; this kind of soils usually develops in humid to subhumid conditions with a well defined dry season.

The other three samples belong to the phreatic kind, because they share this features: (1) Lack alpha fabrics. (b) Coarse-grained texture [chiefly gravel and medium to coarse sand]. (3) Weak reaction to $\mathrm{HCl}$. (4) Strong carbonate cementation. (5) Lack of organic remains. These samples are best interpreted as part of a channel lag deposit permeated by carbonate-rich phreatic water under conditions of a high phreatic level.

Finally, an indirect but strong evidence of paleosol and vegetation development in the study area is afforded by the small but quite significant Paso del Águila local fauna [Ferrusquía-Villafranca et al. (2014)], which was collected from these deposits [Figures 6D-E]. It consists of at least two species of the equid Pliohippus, whose odontography suggests a Late Miocene age [no younger than Clarendonian and no older than Hemphillian NALMAs (North American Land Mammal Ages; Tedford et al., 2004)], a large camelid, and a cervid. The fauna calls for a subhumid, savanna and forest [with a well developed understory] biome to support it, which in turn suggests a subtropical environment for the San Nicolás Tolentino area at that time. The pollen assemblage [Figures 7-8] includes both savanna and forest taxa, thus supporting this interpretation.

\subsection{Lacustrine system}

Deposits of this kind crop out in the northern part of the area, forming a geomorph of closely spaced narrow gorges or barrancos, which in due time, evolve into badlands. Where they overlie floodplain deposits, the contact is gradual through an alternate sequence of calcitic, friable clay/silt and limestone set in thin strata; the first tend to be thicker than the latter ones. Both bed thickness and carbonate content increase upward, till limestone strata $0.25 \mathrm{~m}$ or more start to appear [Figure 12], and become dominant. When such strata are uncovered, they weather out forming a mantle of unconsolidated, angular limestone clasts [quite reminiscent of a brecciod conglomerate deposit]; further weathering/erosion leads to incision, gorge-genesis and eventually to badlands. The key fact is the very different erosion-resistance of the limestone and clay/silt beds, as well as their particular thickness and stacking.

The small size outcrop area of the lacustrine sediments, lead us to think that they record pond deposition occurring in lowlands of the floodplain, where water accumulated regardless of the dry/wet seasonal cycle, and that water was carbonate-rich. However, in an attempt to discriminate lacustrine facies [following the Talbot and Allen's (2008) system], we found that the carbonate and fine clastics facies could readily be identified, whereas the shore lake and mud flats facies were barely discernible.

\subsubsection{Lacustrine carbonate and clastic facies}

The lacustrine limestone strata [Figures 12A-C] consists of very thin to mediumly bedded [ 0.1 to $0.35 \mathrm{~m}$ thick], well indurated, limy tuffaceous siltstone made up of volcanic glass shards set in an abundant microcrystalline calcite matrix [glass shards:calcite matrix ratio is $\sim 1: 0.5$ ]; it is a rather uncommon lithic type, which records synsedimentary explosive volcanism nearby; the ash fell in the bottom of a carbonate-rich pond. The presence of thin pyroclastic sheets [consisting of friable, silicic, vitric ash-fall tuffs; see below], sparsely interbedding the floodplain and other deposits of the San Nicolás Formation, further attests this fact.

The thicker strata's upper and lower surfaces are not flat or smooth, but show tube-like casts, spheroid to irregularly-shaped prominences, depressions and hollows, which are interpreted as evidences of submerged/rooted vegetation [and associated limnic biota] inhabiting a pond that remained shallow to very shallow most of the time; however, no actual fossils were found.

The limestone strata are interbedded by yellowish, friable, calcitic clay and clayey siltstone [grains are mostly straight-extinction quartz], set in laminated to very thin strata that may form stacks up to $0.3 \mathrm{~m}$ thick [Figure 12D]. The lime-rich/lime poor bed alternation discloses an episodic lime-rich water supply, which probably proceeded from intermittent springs ultimately tapping aquifers in the buried carbonate Cretaceous sequence of the area.

\subsubsection{Lacustrine shore and mud flat facies}

In a few places typical lacustrine limestone strata gradually changed to others formed by poorly indurated, fine sand to silty clay grading to mud; stratal thickness varies from thin to medium; a vague laminar to very low angle planar cross-bedding is discernible; they are interpreted as shore and mud flat facies. No nearshore/offshore facies were detected, which suggests that the lake/pond was not extensive. Finally, the lacustrine facies s.l. lateral contact with the fluvial system is not exposed, but probably occurred through complex intertonguing.

\subsection{Other Systems: Debris flow and Volcanic}

\subsubsection{Gms and Sm Lithofacies: Debris flow and gravity flow deposits}

These deposits include the SG architectural element, and consist of matrix-supported, pebble to cobble, breccioid conglomerate devoid of bedding or other sedimentary structures. One such deposit was detected in the area [located in the southern part]. The presence of deposits consisting of thick to massively bedded [ $>3 \mathrm{~m}$ thick], 

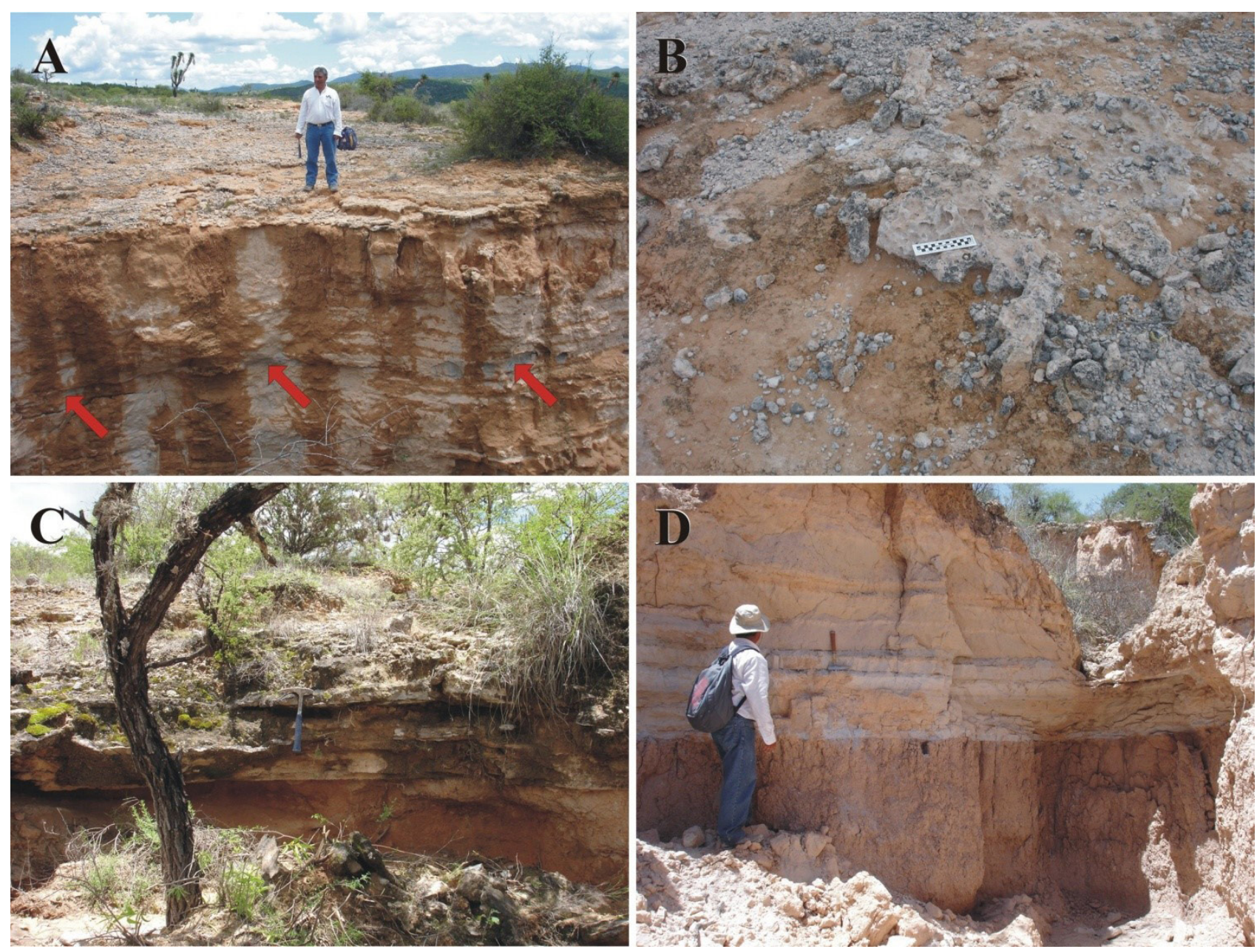

Figure 12. San Nicolás Formation's depositional systems, lacustrine deposits. A-C. Lacustrine carbonate facies: The localities respectively lie $\sim 2.3 \mathrm{~km}$ NW of Paso del Águila ["area of canyons"]. A. Thinly bedded, well indurated, erosional-resistent, lacustrine limestone heavily weathered to a sheet-like mass of angular clasts; its presence promoted the formation of small canyons developed in the lacustrine fine clastics, which show lamination; a thin sheet of friable, rhyolitic ash-fall tuff [pointed by arrows] lies $\sim 1.6 \mathrm{~m}$ below the ground surface. North lies to the right of picture. B. Thin sheet of angular to subrounded gravel clasts of lacustrine limestone resulting from intense weathering of an exposed bed. North lies to the right of picture. C. Small sequence of well indurated, ledge-forming, thinly bedded lacustrine limestone and thin to mediumly bedded, fine-grained lacustrine clastics. North lies to the left of picture. D. Lacustrine fine clastics set in thick strata of friable, silty claystone [lower part], and of clayey siltstone [upper part]. North lies to the left of picture.

fine- to medium-grained sandstone, siltstone and/or silty claystone, usually containing scarce gravel clasts, and showing no discernible internal structures [Figures 13A$\mathrm{B}]$, is interpreted as recording fine sediment gravity flow. Such deposits are related to bank collapse and liquefaction [Collinson (1996), Miall (2006)]; they were observed intercalated with channel sandstone. The debris flow system is not frequent.

\subsubsection{Pyroclastic sheets}

These sheets [Figures 13C-D] although do not conform a depositional system per se, are briefly described, because they did contribute to generate the San Nicolás Formation, help to date it and to understand their depositional history. This "facies" consists of friable, unconsolidated to slightly lithified, silicic, vitric ash-fall tuff sheets $[<0.4 \mathrm{~m}$ thick] sparsely interbedded throughout the unit, particularly in the upper part [see Part 1, Figures 13C-D and 17A-B; this issue]. This and the previous system are volumetrically much less important than the fluvial and lacustrine systems, but equally significant to understand the makeup, genesis and evolution of this unit.

\subsection{Concluding Remarks on the San Nicolás Formation's Depositional Systems}

The preceding information discloses that the Fluvial System vastly out volumes the other depositional systems in the composition of the San Nicolás Formation. In turn, this system includes both sand-dominated sections [Figure 4C] and gravel-dominated sections [Figure 4B]; however, the first volumetrically prevails over the other, as even a cursory examination of the cliffs laying along Río San Nicolás shows. In fact, an analysis of this unit's vertical 
profile allows a rough approximation of the gravel:sand ratio, which is 1.0:0.25.

This fact is unexpected, because the San Nicolás depositional area [i.e., the Peotillos-Tolentino Graben] lies close to the source-area [i.e., the Cretaceous carbonate horsts that bound the graben]. In such setting, one would expect gravel-dominated fluvial deposition. It might be that San Nicolás fluvial network was fed by currents that traversed easternly long distances in the Sierra Madre Oriental ranges, so that a significant amount of its coarse gravel load was dumped before reaching the mentioned graben.

Another feature worth considering, is the large thickness [ 1100 m] of the San Nicolás Formation compared with its limited exposed areal extent across the Peotillos Tolentino
Graben [not lengthwise; see Figure 2]. The cause is probably related to the transversely narrow accommodating space afforded by the Graben, which favored vertical aggradation/ accretion over lateral accretion. Additional work is needed to further elaborate on this matter.

\section{Other aspects of the San Nicolás Formation}

4.1. Tectono-sedimentary evolution of the PeotillosTolentino Graben and its fill: A first interpretation approach

The previous lithofacies study and the available geologic information indicates that the San Nicolás Formation
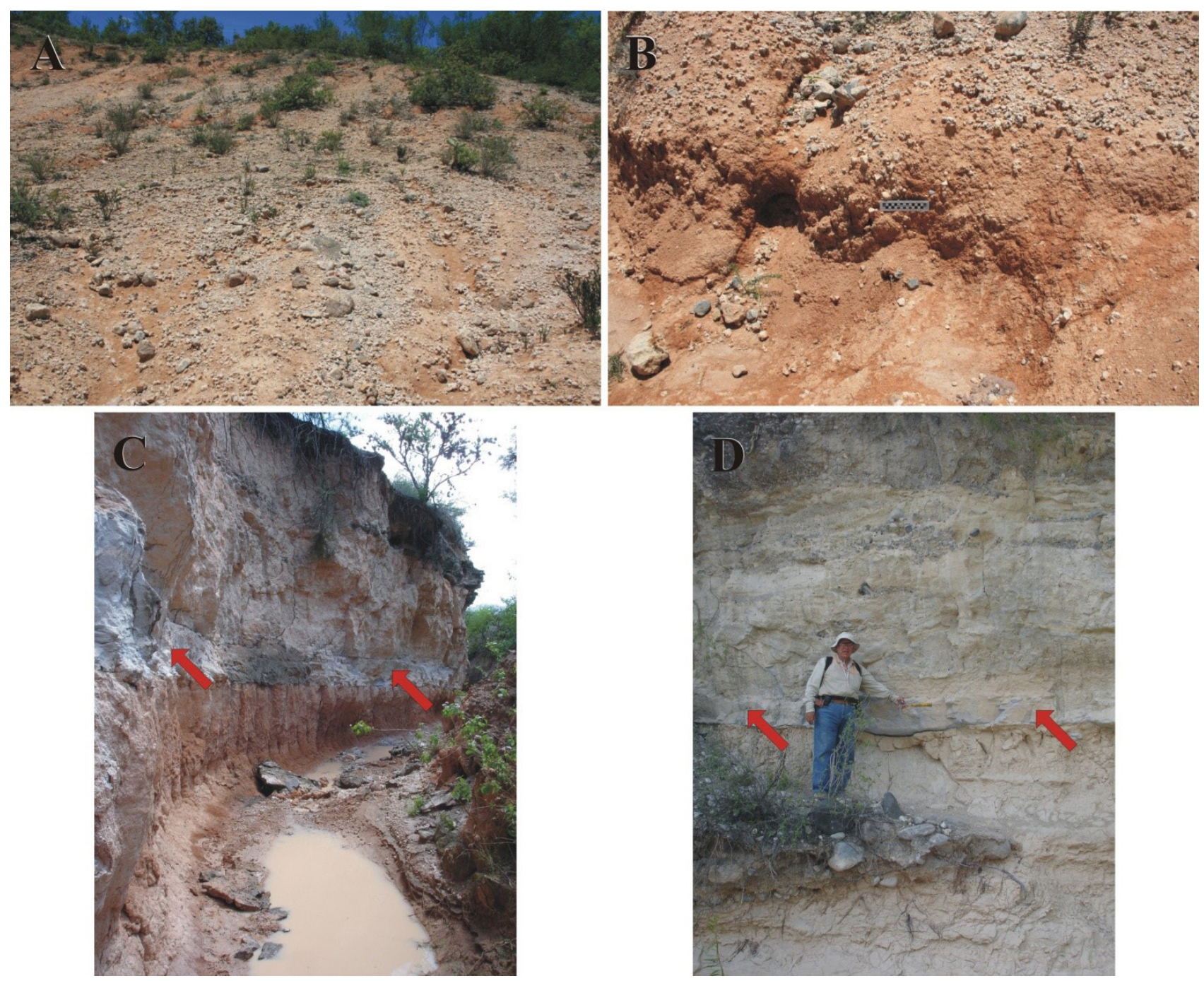

Figure 13. San Nicolás Formation depositional systems, other deposits. A-B. Debris flow deposits: The site lies $\sim 2.5 \mathrm{~km}$ NW of Morenos. A. Matrixsupported, structureless calcilithitic conglomerate. East lies to the right of picture. B. Closer view showing the abundance of matrix. North lies to the right of picture. C-D. Tuff sheets: The localities respectively lie $\sim 2.3 \mathrm{Km} \mathrm{NW}$ of Paso del Águila ["area of canyons"], and $\sim 1 \mathrm{~km}$ SE of this village, on the Río San Nicolás [eastern cliff]; C. An $\sim 40 \mathrm{~cm}$ thick sheet of light gray, friable, rhyolitic ash-fall tuff [marked by arrows] interbedding lacustrine fine clastics set in thick to very thick strata. East lies to the right of picture

D. An $\sim 35 \mathrm{~cm}$ thick sheet of light gray, friable, rhyolitic ash-fall tuff [marked by arrows] interbedding a fluvial sequence consisting of moderately indurated, low angle tabular cross-bedded sandstone set in medium to thick strata, partly intertongued by conglomerate lenses and sheets. North lies to the right of picture. 
was deposited in an actively subsiding, NNW elongate graben/basin, surrounded by horsts [i.e., block-mountains consisting of Cretaceous carbonates], under humid to subhumid climatic conditions that allowed the vigorous erosion/removal of large volumes of clastic sediments, as well as the development of a competent axial fluvial network capable of transporting/depositing such large clastic volumes. This network must have included several major channels, where abundant coarse- grained clastic deposits of various kinds were laid down. Probably such channels, particularly the main one were strongly meandered, on account of the relatively wide extension of the floodplain facies. On the other hand, the well developed succession of channel lag and bar deposits seen on the cliffs along present-day Río San Nicolás suggests that they were laid down by a major channel, located close by, [i.e., near the eastern flank of the Peotillos-Tolentino Graben], and that it probably functioned as an axis for this fluvial network, which seems to have drained northwardly, as the tectonic framework may indicate [the graben is nearly closed on the south, by the Morenos Village]. This presumption could not be corroborated though, because most gravel-clasts are isodiametric, precluding their imbrications and use as paleocurrent indicators; further, the cross-bedding directions were too variable to disclose a preferred direction.

The present-day Río San Nicolás and its fluvial network drain the area southwards, passing through a gorge by the village Morenos, reaching a small plain set just south of it [see Figure 2]. Assuming that the river network that laid down San Nicolás Formation flowed northward, it becomes necessary to explain this shift in flow direction. The Pleistocene volcanic bodies in the area's northwest [Las Joyas and Pozo del Carmen units], may have played a role in such shift: (a) Their emplacement may have blocked the drainage, diverting it southwards. (b) Magmatism associated to this emplacement might cause local upheaval, producing a slight slope to the south, which favored the shift. On the other hand, the geomorphic features of Río San Nicolás are those of a "juvenile" stream [e.g. low sinuosity, not deeply incised channel and narrow plains], thus lending further credence to this contention.

Tectono-sedimentary-climatic conditions remained approximately stable long enough to allow the deposition of a stratal pile at least $1100 \mathrm{~m}$ thick. This in turn suggests some "coupling" between erosion rate and deposition rate, i.e., between sedimentary supply and accommodating space [ultimately related to horst uplift and/or graben/basin subsidence, or both]. The available information does not allow us to discriminate the contribution of either to San Nicolás Formation genesis. At any rate, this thick stratal pile indeed records the recurrent/cyclic superimposing of the aforesaid fluvial network depositional systems through time. Figure 14 affords a glimpse of this record: It pictures a $\sim 100 \mathrm{~m}$ long, continuous sequence along the western bank of Río San Nicolás [at a site located $\sim 1 \mathrm{~km}$ south of the namesake town], where three channel lag/bar and laterally intertonguing sand sheets are superposed to each other. Multistorey sheets with little overbank deposits usually indicate first lateral mobility of high energy bed-load streams [Collinson (1996)]. On a broader perspective, they evidence recurrent/cyclic fluvial deposition.

Assuming a near horizontal base level for deposition in this fluvial network, and the lateral extension and gradation/ intertonguing of adjacent depositional systems, it follows that an approximately continuous sheet-like stratiform body was formed in the Peotillos-Tolentino Graben, and that the narrowness of the graben favored vertical over lateral accretion, eventually producing the observed stacking of stratiform bodies; such stacking records recurrent/cyclic depositional events.

Cycle control was probably climatic, somehow tuned to tectonic activity; however, additional work is needed to prove it. By contrast, the flat-laying, clastic Quaternary units, which are $>40 \mathrm{~m}$ thick, show much less stacking, so that nowhere a three-story stack was observed, thus suggesting that only one- or at best two-cycles of fluvial deposition events have been recorded.

In addition, a smaller "subsidiary" lacustrine system also developed; it was intermittently fed by lime-rich spring water, where fine clastic deposition occurred. Outside but near the area, silicic explosive volcanism "episodically" took place, emplacing thin, vitric ash-fall tuff sheets at different stratal levels, as the San Nicolas Formation was depositing.

4.2. Paleoclimate during San Nicolás Formation deposition time

Three lines of evidence may help to disclose aspects of this subject. The depositional systems just described, call for a much more humid climate regime than the one prevailing nowadays, whereby an extensive and competent fluvial network could be developed and sustained long enough to generate at least, a $1100 \mathrm{~m}$ thick stratal pile. Both the Paso del Águila mammal fauna and the San Nicolás palynoflora, as discussed earlier, support this contention; in fact, the latter include taxa known to thrive in temperate/humid climatic conditions. The phreatic-generated calcretes [which call for high phreatic levels, and in turn indicators of humid climate], lend further support to this interpretation.

Was the climate uniform/equitable or it included dry periods? The paleosols may hold the answer. Luvisols require humid conditions that should remain stable for a long time. Therefore, the thick luvisols evolved on the fine-grained floodplain deposits, indicate long periods of climatic stability. However, the presence of calcisols [which develop in humid to subhumid climate with a well developed dry season], indicate that the area was also subjected to dry condition-intervals. Only a detailed paleosol study may bring accord to these contrasting interpretations, here we tentatively suggest that climate during the whole San Nicolás deposition time was dominantly equitable 

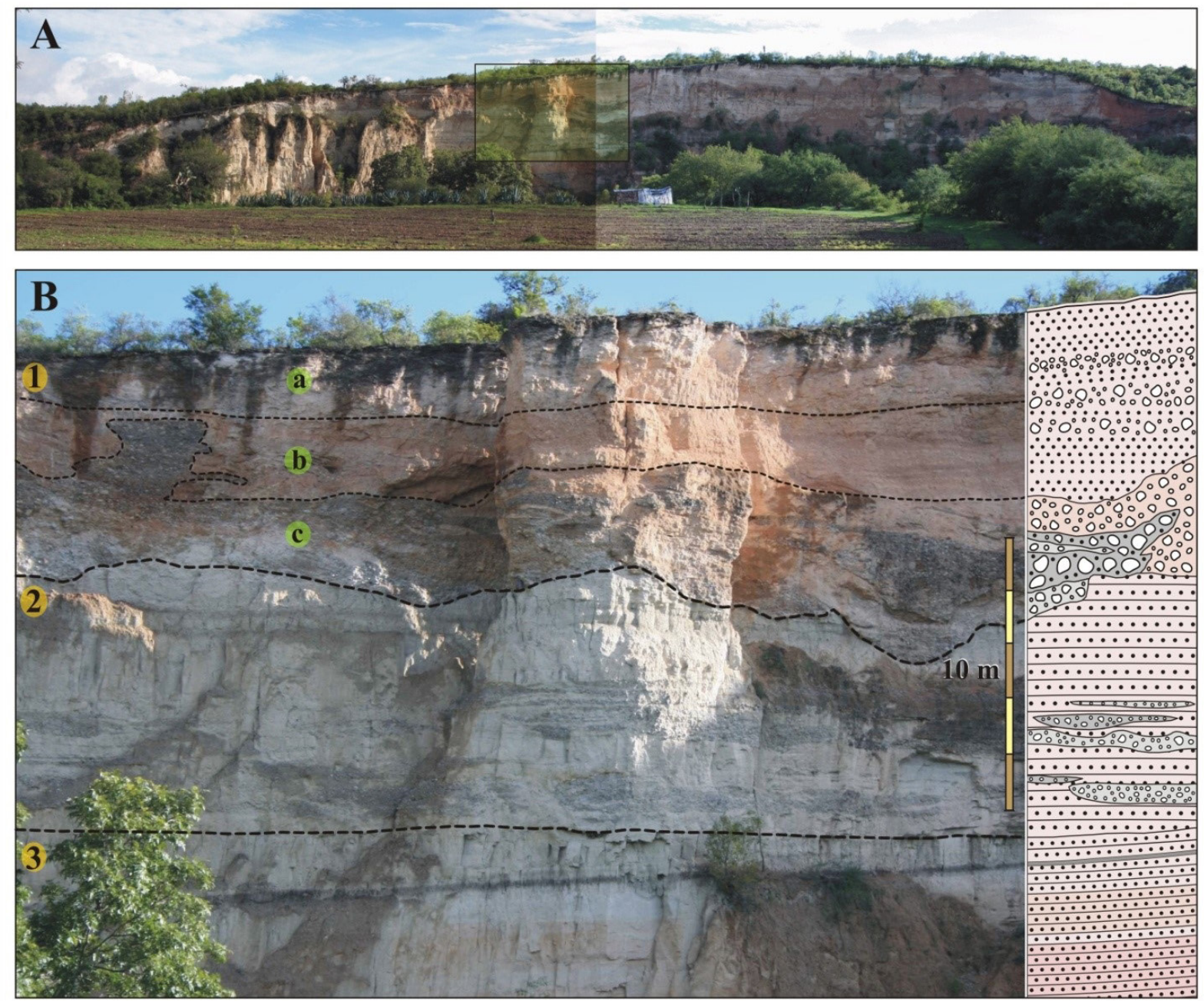

Figure 14. San Nicolás Formation's stacking of fluvial systems: The locality lies $\sim 1.1 \mathrm{~km}$ south of San Nicolás Tolentino, it is the cliff carved by the Río San Nicolás on this unit. A. Panorama [looking north] of a fluvial systems stacking, inset square shown in B; the outcrop is $\sim 320 \mathrm{~m}$ long. B. A stack of three superposed, sheet-like fluvial systems [lower, middle and upper], which largely consist of channel and associated sandstone deposits, and are interpreted as the record of three cycles of fluvial deposition. Line delineation helps to distinguish the stacking; subdivision of the systems into subsystems [e.g. upper a-c] is not further pursued to avoid obscuring the space relationships of particular deposits. Column on the right shows major sedimentary attributes of the stratal stack. East lies to the right of picture. Scale bar $=10 \mathrm{~m}$.

[temperate and humid to subhumid], but at times became unequitable [temperate humid to subhumid most of the year, and seasonably "hot" and dry], as present-day eastern Oaxaca [García (1990)].

4.3. Plant taxa/communities as gauges of paleolaltitude, uplift/subsidence rate, and timing

As shown above, the presence of altitudinally significant taxa in the San Nicolás Palynoflora [Table 1, and Figures 7-8], indicate that: (a) It was laid down in a basin set at $\sim 2000$ masl. (b) Such altitude was reached by Late Miocene Time. (c) The altitude has remained essentially unchanged ever since. Data of this kind from other basin fills in grabens across the Sierra Madre Oriental Morphotectonic Province, may provide basic information on its rate of uplift, and whether it was uniform throughout, or it showed significant "subprovincial" changes [i.e., faster/slower in some parts as compared with others], or whether it was synchronous, diachronous or non-synchronous across the whole province, et cetera]. In turn, information of this sort would greatly improve current understanding on the Cenozoic tectonic evolution of the Sierra Madre Oriental. Flynn et al. (2002) have contributed to detect the timing and probable rate of uplift of the Southern Andes [Chile], utilizing mammal faunas, but the rationale is similar.

4.4. Paleosols in badlands of the San Nicolás Formation: A relevant discovery

Because of their economic importance, Mexico's soils have been widely studied for a long time [ $c f$. INEGI (2007), Flores-Román et al. (2009), Solleiro-Rebolledo and Gama Castro (2011), Krasilnikov et al. (2013) and lit. therein], 
however paleosols are much less known; in fact most studies concerning them have been conducted within archaeological projects, and pertain mostly to the Late PleistoceneHolocene [cf. Gama-Castro et al. (2005"a"-“b”), McClung et al. (2005), Solleiro et al. (2006), Rivera-Uria et al. (2007), Balcells-González et al. (2011), Jasso-Castañeda et al. (2012), Pérez-Pérez et al. (2012)]. Thus, the unquestionable finding of thick relict Luvisols in the badlands developed in the floodplain strata of the Late Miocene San Nicolás Formation, as well as of other kind of paleosols within and on the peneplained deposits of this unit, makes them the oldest paleosols reported -albeit briefly- from this country [cf. Sedov et al. (2003), Ferrusquía-Villafranca et al. (2010)]; therefore, such discovery is a major contribution to the study of paleosols in Mexico.

\section{Summary and Conclusions}

1. The Peotillos-Tolentino Graben, southwestern Sierra Madre Oriental Morphotectonic Province at central San Luis Potosí, bears a sedimentary fill largely composed of the Late Miocene San Nicolás Formation, an $\sim 1100$ m thick continental clastic sequence; it chiefly includes a fluvial depositional system, and subsidiary systems [lacustrine, debris flow and pyroclastic], which volume-wise contribute little to its makeup.

2. In the fluvial system, a first-approach lithofacies discrimination was performed, which allowed to distinguished these kinds of deposits: Channel lag, bar [of various types], floodplain, channel conglomerate and/or channel sandstone, levee, and crevasse splay deposits. Within the lacustrine system, carbonate and clastic deposits were readily recognized. The climate prevailing during deposition of San Nicolás was certainly much more humid than the current one. Additionally, thin rhyolitic ash-fall tuff sheets interbed at different levels the fluvial sequence.

3. The floodplain facies yielded the small, but significant Paso del Aguila local fauna, which consists of both open country elements [e.g. pliohippine horses and camels], and forest dwellers [like the cervids]. Such mammal assemblage could only have thrived under a much more humid climate regime than the present-day one. The San Nicolás Palynoflora, also collected from the same deposits, consists too of open country taxa [e.g. Mopites, Alnipollinites, which form mesophyllous forets, and the fern Polypodium], and mountain slope taxa [e.g. Pinus and Liquidambar]; the climate inferred from the palynoflora is humid to subhumid, thereby independently corroborating the inference on the climate based on sediments and mammals. Finally, the paleoluvisols developed in the floodplain deposits affords additional independent corroborative evidence to such interpretation.

4. The discovery of pre-Pleistocene paleosols in the Peotillos-Tolentino area is a significant contribution in the study of paleosols in Mexico. Likewise, the use of plant taxa as paleoaltitude indicators when coupled with reliable time markers, affords a valuable, but little used tool in Mexico to study uplift rate.

Data so obtained could enhance understanding of regional tectonic evolution [in this instance that of the Sierra Madre Oriental Morphotectonic Province].

\section{Acknowledgments}

Institutions: The Authors duly thank Dirección General de Asuntos del Personal Académico de la Universidad Nacional Autónoma de México [DGAPA, UNAM], for supporting this research through grant PAPIIT IN107210; they also thank their home institutions, Instituto de Geología, UNAM and Instituto de Geología, UASLP for all the facilities conceded to develop this project.

Persons: We are very grateful to Dr. José Rafael Barboza Gudiño and an anonymous reviewer for their able review, which greatly improved the manuscript. The authors gladly acknowledge the students Jasmin Jhanely Carera Ortega and Ana María Rocha Juárez for their assistance in several aspects of the project. We also thank Mr. Cándido Ortíz Moreno, a native of Paso del Águila, for his kind and efficient field assistance.

\section{Referencias}

Arakel, A.V., 1982, Genesis of Calcrete in Quaternary Soil Profiles, Hutt and Leeman Lagoons, Western Australia: Journal of Sedimentary Petrology, 52, 109-125.

Axelrod, D.I., Raven, P.H., 1985, Origins of the Cordilleran flora: Journal of Biogeography, 12, 21-47.

Balcells-González, J.A., Gama-Castro, J.E., Mirón-Marván, E., 2011, Recent Investigationes in the Salto de Agua Region: Sites, Territorios and Frontiers to the West of Palenque: San Francisco California. EU., PreColumbian Art Research Institute, The Pari Journal XI, 4, 3-11.

Barbour, M.G., Billings, W.D. (eds.), 1988, North American terrestrial vegetation: Cambridge, U.S.A., Cambridge University Press, 434 p.

Batten, J.D., 1999, Small palynomorphs, in Jones, T.P., Rowe, N.P. (eds.), Fossil plants and spores: Modern techniques: Geological Society of London, 15-19.

Boggs, S. Jr., 2009, Petrology of sedimentary rocks: Cambridge, U.S.A., Cambridge University Press, 600 p.

Collinson, J.D., 1996, Sedimentary Environments; Processes, Facies and Stratigraphy: Alluvial sediments: Blackwell Publishing Company, 37-82.

Food and Agriculture Organization of the United Nations, International Soil Reference and Information Center, Soil Sciences International Society (FAO, ISRIC, SCIS), 1998, World reference base for soil resources (WRB), Report: Rome, 84, 90 p.

Ferrusquía-Villafranca, I., Arroyo-Cabrales, J., Martínez-Hernández, E., Gama-Castro, J., Ruiz- González, J., Polaco, O.J., Johnson, 
E., 2010, Pleistocene mammals of Mexico: A critical review of regional chronofaunas, climate change response and biogeographic provinciality: Quaternary International, 217, 53-104.

Ferrusquía-Villafranca, I., Ruiz-González, J., Torres-Hernández, J.R., 2011a, A new Miocene local fauna from the Sierra Madre Oriental at San Luis Potosí, Central-East Mexico, and its Paleontologic Significance: Society of Vertebrate Paleontology 71st Annual Meeting, Program and Abstacts, 108.

Ferrusquía-Villafranca, I., Ruiz-González, J., Torres-Hernández, J.R., Martínez-Hernández, E., 2011b, Depositional systems of the San Nicolás Unit, Peotillos Graben, Sierra Madre Oriental at San Luis Potosí, Central-East Mexico: A first approach: Geological Society of America, Annual Meeting \& Exposition, Abstracts with Programs, Abstracts with Programs, 43, 548.

Ferrusquía-Villafranca, I., Ruiz-González, J.E., Martínez-Hernández, E., Torres-Hernández, J.R., Woolrich-Piña, G., 2014, A new Miocene local fauna from the Sierra Madre Oriental at San Luis Potosí, central-east Mexico, and its paleontologic significance: Geobios, 39, 771-784.

Fisher, R.V., Schmincke, H.U., 1984. Pyroclastic Rocks. Berlín: SpringerVerlag, $472 \mathrm{p}$.

Flores-Román, D., Vela-Correa, G., Gama-Castro, J.E., Silva-Mora, L., 2009 , Pedological diversity and the geoecological systems of Sierra de Guadalupe, central Mexico. Diversidad pedológica y los sistemas geoecológicos de la Sierra de Guadalupe, centro de México: Revista Mexicana de Ciencias Geológicas, 26, 609-622.

Flynn, J.J., Novacek, M.J., Dodsond, H.E., Frassinettie, D., McKennac, M.C., Norellc, M.A., Sears, K.E., Swisher, C.C., Wyss, A.R., 2002, A new fossil mammal assemblage from the southern Chilean Andes: implications for geology, geochronology, and tectonics: Journal of South American Earth Sciences, 15, 285-302.

Folk, R.L., 1974, Petrology of sedimentary rocks: Austin, Hemphill, 184 p. Gama-Castro, J.E., McClung de Tapia, E., Solleiro-Rebolledo, E., Ibarra, E., Sedov, S., Jasso-Castañeda, C., Vallejo-Gómez, E., Pi-Puig, T., Cabadas-Báez, H., 2005a , Incorporation of ethnopedological knowledge in the study of soils in the Teotihuacan Valley, Mexico: Eurasian Soil Science, 38, 95-98.

Gama-Castro, J., Solleiro-Rebolledo, E., McClung, E., Villalpando, J.L., Sedov, S., Jasso-Castañeda, C., Palacios, S., Hernández, D., 2005b, Contribuciones de la Ciencia del Suelo a la investigación arqueológica -el caso de Teotihuacan: Terra, 23, 1-11.

García, E., 1990, Climas, IV.4.10, escala 1:4,000,000: México, D.F., Universidad Nacional Autónoma de México, Instituto de Geografía, Atlas Nacional de México, II, 1 mapa.

Instituto Nacional de Estadística, Geografía e Informática (INEGI), 2005a, Carta Topográfica Peotillos F14-A75, escala 1:50,000: México, Aguascalientes, Ags., Instituto Nacional de Estadística, Geografía e Informática, 1 mapa.

Instituto Nacional de Estadística, Geografía e Informática (INEGI), 2005b, Carta Topográfica Santa Catarina F14-A85, escala 1:50,000: México, Aguascalientes, Ags., Instituto Nacional de Estadística, Geografía e Informática, 1 mapa.

Instituto Nacional de Estadística, Geografía e Informática (INEGI), 2007, Conjunto de datos vectoriales de la Carta Edafológica, escala 1:250,000, Serie II: México, Aguascalientes, Ags., Instituto Nacional de Estadística, Geografía e Informática, 1 mapa.

Ingram, R.L., 1954, Terminology for the thickness of stratification and parting units in sedimentary rocks: Geological Society of America Bulletin, 65, 937-938.

Jasso-Castañeda, C., Gama-Castro, J.E., Solleiro-Rebolledo, E., DíazOrtega, J., 2012, Morfogénesis, procesos y evolución del horizonte Bw cámbico en tefrapaleosuelos del volcán Nevado de Toluca: Boletín de la Sociedad Geológica Mexicana, 64, 37-47.

Krasilnikov, P., Gutiérrez, C., Ahrens, R.J., Cruz, S., Sedov, S., SolleiroRebolledo, E., 2013, The Soils of Mexico: Dordrecht, Neatherlands, Springer, $188 \mathrm{p}$.

Martínez-Hernández, E., 1992, Caracterización ambiental del Terciario de la Región de Ixtapa, Estado de Chiapas. Un enfoque Palinoestratigráfico: Universidad, Nacional Autónoma de México,
Revista del Instituto de Geología, 10, 54-64.

McClung, E., Domínguez, I., Gama-Castro, J., Solleiro-Rebolledo, E., Sedov, S., 2005, Radiocarbon dates from soil profiles in the Teotihuacan valley, Mexico: Geomorphological processes and vegetation change: Radiocarbon, 471, 159-175.

Miall, A.D., 1987, Epeirogeny: Is it really orogeny or theology?: Geoscience Canada, 14, 126-127.

Miall, A.D., 2006, 4th Printing, The geology of fluvial deposits: Berlin, Springer-Verlag, $582 \mathrm{p}$.

Miall, A.D., 2010, The geology of stratigraphic sequences: Berlin, Springer-Verlag, $522 \mathrm{p}$.

Pérez-Pérez, J., McClung de Tapia, E., Barba-Pingarrón, L., Gama-Castro, J.E., Peralta-Higuera, A., 2012, Remote sensing detection of potential sites in a prehispanic domestic agricultural terrace system in cerro San Lucas, Teotihuacan, Mexico: Boletín de la Sociedad Geológica Mexicana, 64, 109-118.

Ramos, A., Sopeña, A., 1983, Gravel bars in low-sinuosity streams (Permian and Triassic, central Spain), in Collinson J.D., Lewin, J. (eds), Modern and ancient fluvial systems: International Association of Sedimentologists, Special Publication, 6, 301-312.

Retallack, G.J., 1983, Late Eocene and Oligocene paleosols from Badlands National Park, South Dakota: Geological Society of America Special Paper, 193, $82 \mathrm{p}$.

Rivera-Uria, M.Y., Sedov, S., Solleiro-Rebolledo, E., Pérez-Pérez, J., McCLung, E., González, A., Gama-Castro, J., 2007, Degradación ambiental en el valle de Teotihuacan: evidencias geológicas y paleopedológicas: Boletín de la Sociedad Geológica Mexicana, 59, 203-217.

Schmid, R., 1981, Descriptive nomenclature and classification of pyroclastic deposits and fragments: Recommendations of the International Union of Geological Sciences Subcommission on the Systematics of Igneous Rocks: Geology, 9, 41-43.

Sedov, S., Solleiro-Rebolledo, E., Gama-Castro J., 2003, Andosol to Luvisol evolution in central Mexico: Timing, mechanisms and environmental setting: Catena, 54, 495-513.

Solleiro-Rebolledo, E., Gama-Castro, J.E., 2011, El material parental como factor geográfico en la distribución de los suelos, in Krasilnikov, P. (ed.), La geografía de los suelos de México: México, Universidad Nacional Autónoma de México, Facultad de Ciencias, 41-56.

Solleiro-Rebolledo, E., Sedov, S., McClung, E., Cabadas, H., Gama-Castro, J., Vallejo-Gómez, E., 2006, Spatial variability of environment change in the Teotihuacan valley during late Quaternary: paleopedological inferences: Quaternary International, 156/157, 13-31.

Talbot, M.R., Allen, P.A., 2008, Lakes, in H.G. Reading, (ed.), Sedimentary Environments-Processes, Facies and Stratigraphy: Malden, Mass, Blackwell Publishing, 83-124.

Tedford, R.H., Albright III, L.B., Barnosky, A.D., Ferrusquía-Villafranca, I., Hunt, R.M., Storer, J.E., Swisher III, C.C., Voorhies, M.R., Webb, S.D., Whistles, D.P., 2004, Mammalian Biochronology of the Arikareean through Hemphillian interval (Late Oligocene through Early Pliocene Epochs), in Woodburne, M.O. (ed.), Late Cretaceous and Cenozoic Mammals of North America: New York, Columbia University Press, 169-231.

Tiffney, B.H., Manchester, S.R., 2001, The use of geological and paleontological evidence in evaluating plant phylogeographic hypotheses in the Northern Hemisphere Tertiary: International Journal of Plant Science, 162, S3-S17.

Wijnga, V.M., 1995, A first approximation of montane forest development during the Late Tertiary in Colombia, in Churchill, S.P., Balslev, H., Forero, E., Luteyn, J. (eds.), Biodiversity and Conservation of neotropical montane forest: New York, The New York Botanical Garden, 23-34.

World Reference Base for Soil Resources (WRB), 2006, World Soil Resources Report No. 103: Rome, United Nations Food and Agriculture Organization, $128 \mathrm{p}$.

Manuscrito recibido: May 9, 2013

Manuscrito corregido recibido: March 13, 2014

Manuscrito aceptado: April 8, 2014 